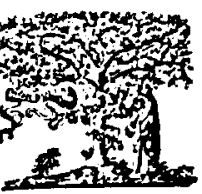

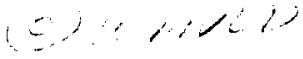

$0+2, y+1$

Journal of Biotechnoiogy +7 (1996) 289-312

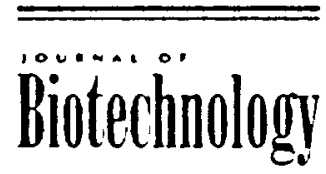

ELSEVIER

\title{
Feeding frequency affects cultured rat pituitary cells in low gravity
}

\author{
IV.C. Hymeri* , R.E. Grindeland ${ }^{b}$. T. Salada`. R. Cencił, K. Krishnan ${ }^{\star}$, C. Mukaic, \\ S. Nagaokac

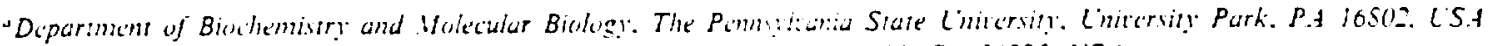

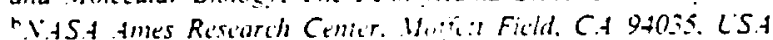 \\ - Vurional Space Darelopment fancy of Japam. Sharaki. sas. Japan
}

Received 2 October 1995: revised is Decemier i995: accepted 23 December 1995

\begin{abstract}
In this report. We describe the results of a rat pituitary eil sulture experiment done on STS-6: in which the effett of cell feeding on the release of the six anterior pituitar: homones uas studied. We found complex micrograsity-related interactions between the frequency of cell feeding and the cliantity and quality (i.e. biological activity of some of the six hormones released in flight. Analyses of grow th hermone (GH) released from cells into culture media on different mission days using gel filtration and ion exchange chromatography yielded qualitatively similar results between ground and fight samples. Lack of cell feeding resulted in extensive cell clumping in flight (but not ground) cultures. Vigorous fibroblast growth occurred in both grouns and fight cultures fed 4 times. These results are interpreted within the context of autocine and or paracrine feadback interactions. Finally, the puyload specialist successfully prepared a fresh inpsin solution in microgravit!. detached the cells from their surface and reinserted them back into the culture chamber. These cells reattached and continued to release hormone in microgravity. In summary, this experiment show's that pituitary cells are micrescavity sensitive and that coupled operations routinely associated with laboratory cell culture can also be accomplished in low gravity.
\end{abstract}

Keywords: Rat pituitary cell culture: Microgravity

\section{Introduction}

If and how cells sense microgravity has been thoughtfully considered, modeled and debated for

\footnotetext{
- Corresponding author. Department of Biochemistry and Molecular Biology. The Pennsylvania State University, University Park. PA 16803, USA

${ }^{1}$ Presented in part at the American Society of Gravitational and Space Biology Meetings. Washington, DC 1995.
}

some time. Many different types of cells have been exposed to low gravity; some show significant and repeatable changes (Halstead et al., 1991; de Groot et al., 1990; de Groot et al., 1991; Limouse et al., 1991; Cogoli, 1993).

Our group has studied rat anterior pituitary gland cell structure and function during and after spaceflight (Hymer et al., 1992; Grindeland et al., 1987). We have focused on synthesis and release 
of growth hormone (GH) and prolactin (PRL) molecules because these two protein hormones are known to participate in the regulation of musculoskeletal, immune. vascular, metabolic and endocrine systems; systems which are often changed in low gravity. We recently reported that pituitary cells, in a passive cell culture system in low gravity, show differences in the quantity and quality (bioactivity) of $\mathrm{GH}$ and PRL released from primary rat pituitary cells in vitro ( $\mathrm{H}_{y}$ mer et al., 1996a: Hymer et al.. 1996b). Interestingly. some of these changes were similar to those found in pituitary cells prepared from spacefloun rats after $7-14$ days in microgravity.

The unique design of the cell culture hardware available for this experiment permitted us to study, for the first time, possible effects of cell feeding on hormone release from each of the six major hormone-contuining cell types. It also provided the astronaut the opportunity to prepare fresh solutions from preweighed powders and use them to trypsinize the anchorage dependent pituitary cells from their surface.

This experiment not only demonstrated that coupled technologies routinely associated with cell culture procedures on earth could be accomplished in the unique low gravity environment, but also showed that important microgravity changes in the quantity and quality of certain hormones released from this mixed cell culture occurred. In some cases, these changes were positively correlated with the frequency of cell feeding during 14 days in space.

\section{Materials and methods}

\subsection{Animals and tissue processing before fight}

Care and use of animals for this experiment that was done on the Space Shuttle in 1994 (STS65) was approved by IACUC committees at Penn State and NASA Ames Research Center and conformed to NIH guidelines. Three days before launch, 150 specific pathogen-free Sprague Dawley male rats (200-220 gms, Harlan Sprague Dawley, Frederick, MD) were killed by decapitation and their anterior pituitary glands dissociated into a single cell suspension that routinely yields 2-2.5 $\times 10^{6}$ cells from each gland (Hymer and Hatfield, 1983). For this experiment, total cells recovered were $4.8 \times 10^{8}$ with a viability $>95 \%$. As show'n in Fig. $1,4 \times 10^{7}$ cells were seeded into each of six cell culture kits (CCK) specifically designed for cell culture technology in microgravity. Three CCK's were maintained in an incubator designed for spaceflight operations on Shuttle middeck while the other three were kept under similar conditions in the laboratory at Kennedy Space Center. Constant real time monitoring of operational parameters of this incubator in microgravity indicated that the temperature variance between the ground and flight units was $\pm 0.1{ }^{\circ} \mathrm{C}$ : relative humidity ranged between $40-60 \%$ in both units throughout this 17 -day experiment. The culture medium $(15 \mathrm{ml} \mathrm{CCK})$ was identical to that used in a previous rat pituitary microgravity cell culture experiment (Hymer et al. 1996a): viz. modified Eagle's minimum essential medium ( $2 . M E W$ ) containing $5 \%$ calf serum. $0.2 \%$ $\mathrm{XaHCO}_{3}, 25 \mathrm{mM}$ Hepes bulfer $(\mathrm{pH} 7.4)$ and antibiotics.

Culture media in CCK \#1 and \#2 were changed according to the schedule shown in Fig. 1: cells in CCK \#3 were left undisturbed over the entire course of the 17-day experiment.

\subsection{Cell culture hardware.}

The unique design of the CCK and its associated hardware permitted (a) microscopic observation of the primary rat pituitary cells attached to the pronectin-treated polycarbonate surface; (b) removal of spent media and their storage at $20^{\circ} \mathrm{C}$; (c) addition of fresh culture media; and (d) on board preparation of two fresh solutions from preweighed powders stored in syringes $(10 \mathrm{mg}$ Difco 1:250 crude trypsin and 100 $\mu \mathrm{g}$ DNase (Type I, Sigma)).

Results of numerous preflight trials using pituitary cells in CCK's indicated that pretreatment with pronectin (10 $\mu \mathrm{g} / \mathrm{ml}$, Sigma) significantly helped promote cell attachment and also enhanced cell recovery after trypsin (data not shown). The appearance of a CCK and its operational configuration is given in Fig. 2. Basically, 
150 Male Rats

Anterior Pituitary Glands

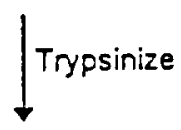

$4.8 \times 10^{\circ}$ cells

1

seed in 5 cell

culture kits (CCK)

3 days before launch

$\left[4 \times 10^{7} \mathrm{cells} / \mathrm{CCK}\right]$
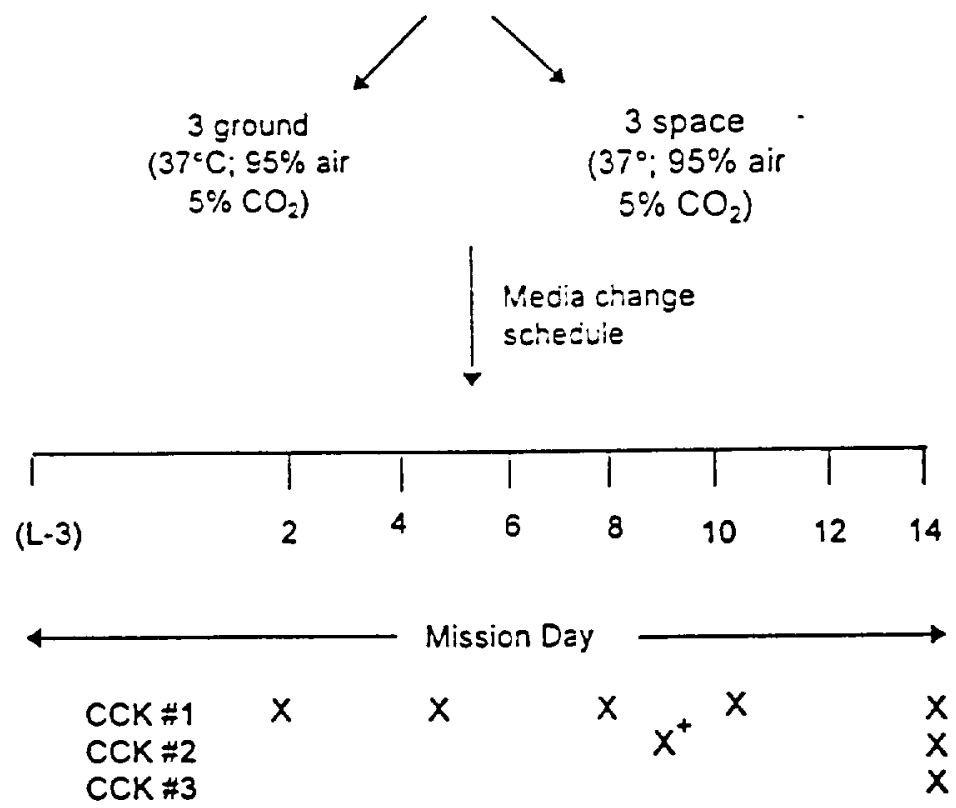

+Trypsinized and replated

Postflight Analysis:

HPLC

Erozen Media

Cells

- Gel filtration

- hormone immunoassay

- flow cytometry

- ion exchange

- (GH, PRL, LH, FSH, TSH, ACTH)

- image analysis

- homone bioassays

- immunocytochemistry

- (GH, PRL)

Fig. 1. Experimental design. See Materials and methods for details. 
this unit consists of (l) a polycarbonate sheet $10.5-\mathrm{mm}$ thick) 10 which the anchorage-dependent pituitary cells attach and 2 two chambers bounded by a $\$ 0-n$ Nucleopore membrane which permits withdrawal and addition of culture medium from the chamber distal to the attached cells. The ripsin solution $3 a 5$ prepared by passing $10 \mathrm{ml}$ of a $5 \mathrm{~m} .1 \mathrm{l}$ Hepes buffered solution containing $30 \mathrm{m.V}$ glycine. $9.2 \mathrm{m.M}$ potassium acetate. $0.5 \mathrm{mYl} \mathrm{M}_{2} \mathrm{Cl}_{2} \cdot 6 \mathrm{H}-0.0 .03 \mathrm{mMlCaCl}$. $220 \mathrm{~m} . \mathrm{ll}$ gl: werol th $\mathrm{mll}$ sucrose and $0.2 \mathrm{mMl}$ $\mathrm{ZnCl}$ and $0.2 \cdot$ EDT A1. $\mathrm{rH}^{-}=6$ into the syringe contuining powdered tr:asin conpled luer

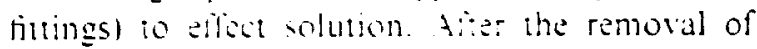
culture madium. this solution ais then added to the attaked cells in $\mathrm{CCK}=2130 \mathrm{~min}$ to promote detactment amonitore microscopically followed by addition of $5 \mathrm{mi}$ of a so bean trypsin inhibitor wlution $11 \mathrm{~m}=\mathrm{mil}$ it.t had been prepured in Hepes buffer labo:al betore launch. The

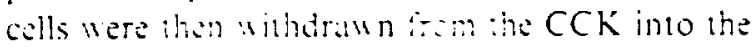
stringe comtaning powderes DVAtse: this solu-
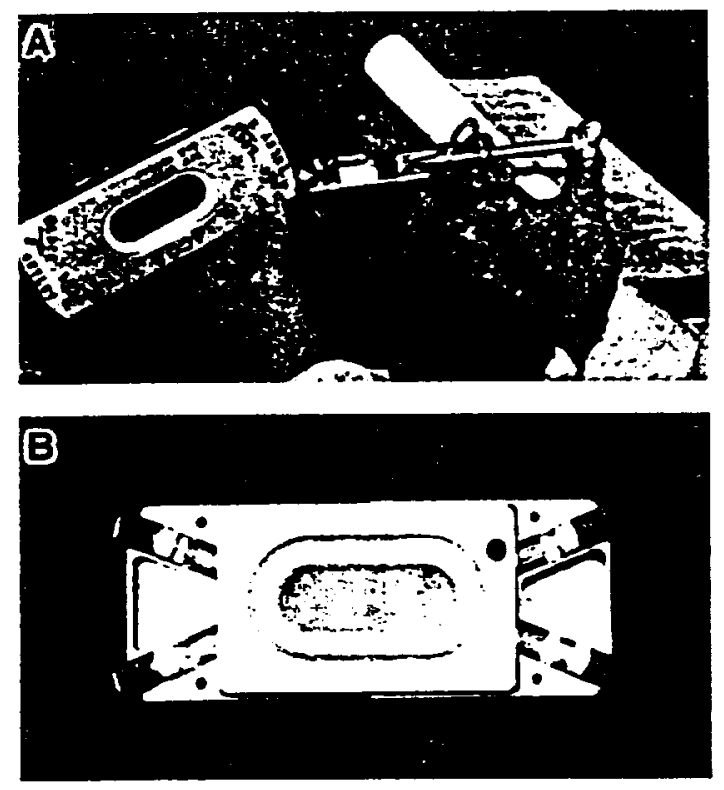

Fig. 2. Coll culture kit (CCK) used in this evperiment. Syringes with luer tittings (A) enable media withdruwal as well as addition of new media: the dciual sulture thumber with its metal alsing removed is also shown (B). See Materials and methods ior additional detuils. (Pliwwstaphs sopied with approval from IASDA: taken from IMIL.? brochurel. tion effectively breaks down nucleoprotein that may have been released from dead cells and routinely results in a smooth suspension of single cells (Hymer and Hatfield, 1983). After withdrawal of the isypsin-trypsin inhibitor solution into a storage syringe. the cells were reinjected into CCK \#2 and $15 \mathrm{ml}$ of fresh culture medium added for continued culture (Fig. 1).

\subsection{Posiffight analysis}

Within $3 \mathrm{~h}$ of Shuttle landing. cells in each of the six CCK's were (a) photographed: (b) media withdraun: (c) cells removed from CCK \#I and $\# 3$ by trypsinization and (d) cells in $\mathrm{CCK} \neq 2$ osmotically lysed by addition of $\mathrm{dH}_{2} \mathrm{O}$ containing $0.2 \mathrm{m.M} \mathrm{ZnCl}$. The viabilities of cells removed from CCK \#1 and \#3 were >80\%. A portion $\left(1 \times 10^{\prime \prime}\right)$ of these cells were used for morphological analysis (see below): the remainder subjected to separation by free flow electrophoresis. Results from this later effort. as well as results of the electrophoretic separation trials of lysed cells. is published in the companion paper.

\subsection{Morgholog!}

Cells in the initial suspension. as well as those recovered at the end of the 17 diy-culture period. were either (a) fixed and processed for immunocytochemical analysis of growth hormone $(\mathrm{GH})$ and prolactin (PRL) cells or (b) multiparameter flow cytometric analyses exactly according to our established procedures that are described in several previous publications (Hatfield and Hymer. 1985; Perez et al.. 1993). Parameters evaluated by flow cytometry (on 10000 cells sample) were (1) $\mathrm{GH}$ cell distributions: (2) marker indices, i.e. the ratio of the voltages of stained to unstained cells - an index of "brightness" of GH-specific fluorescence staining: (3) forward angle light scatter, FALS. (an index of cell size) and (4) perpendicular light scatter, PLS, (an indicator of content of cytoplasmic hormone-containing secretory granules). Procedures for the immunocytochemical analyses of GH stained cells attached to poly-1-1ysine coated cover slips were exactly as described previously (Hatfield and Hymer, 1985); viz. fixation in Zam- 
bonis fluid followed by membrane permeabilization with $0.4 \%$, Triton-x-100); incubation in GHspecific polyclonal antiserum followed by secondary amplification with horse radish peroxidase antiserum. These cell preparations were used for digital analysis of the cytoplasmic area occupied by $G H$ using procedures and equipment identical to those used previously (Hymer et al.. 1992).

\section{5. $H P L C$}

Two different types of chromatography were done to analyze the molecular nature of the immunoreactive $\mathrm{GH}$ ( $\mathrm{GGH}$ ) contuined in the culture media taken from flight and ground $\mathrm{CCK} \# 1$. These were gel iltrution chromalcgraphy to estimate apparent molecular weights of released $\mathrm{G} G \mathrm{H}$ (Hymer et al. 1996a) and anion exchange chromatography to evaluate overall charge character of the released $\mathrm{G} G H$. Sumples from $C C K \# 2$ and $\# 3$ were not analyzed. In all cases. $1-\mathrm{ml}$ aliquots of culture media were lyophilized. and reconstituted in either $500 \mu$ of $0.1 . \mathrm{M}$ potussium phosphute buffer containing $0.05 \mathrm{MNaCl}$. $\mathrm{FH} 7.8$ (gel filtration) or $250 \%$ of $200 \mathrm{m.M}$ TrisHcl. $\mathrm{pH} 7.8$ for anion exchange chromatography.

For gel filtration. each sample was applied to at column of Protein-Pak SW $(7.8 \mathrm{~mm} \times 300 \mathrm{~mm}$. W'aters. Mijford. MA) equilibrated with the same buffer. The column flow rate was $0.3 \mathrm{ml} \mathrm{min}$. The column was calibrated with blue dextran $(2000000$ MII). beta-amylase (200000 $\mathrm{MIN}$ ). bovine serum albumin $(66000 \mathrm{MW})$, carbonic anhidrase $(29000$ $\mathrm{MW}$ ) and ribonuclease $(13683 \mathrm{MW}$ ). The flow rate of the ion exchange column was $0.6 \mathrm{ml}$ min and used a $0.6 \mathrm{M} \mathrm{NaCl}$ gradient for elution.

\subsection{Hormone assays. Growth Hormone (GH)}

Concentrations of immunoreactive GH (iGH) released from cells into culture media were determined by enzyme immunoassay (Farrington and Hymer, 1987). The polyclonal antiserum to $\mathrm{GH}$ has a cross reactivity of $<0.3 \%$ to prolactin at the final dilution (1:80000) used in the assay; each sample was analyzed in duplicate at two dilutions and results are expressed relative to a rat $\mathrm{GH}$ standard preparation (B-11) kindly provided by the National Institute of Diabetes. Digestive, and
Kidney Disease and the National Hormone and Pituitary Program (Lniversity of Maryland School of Medicine).

Concentrations of biologically-active $\mathrm{GH}$ (bGH) in culture media and extracts were determined exactly according to the tibial line bioassay procedure of Greenspan et al. (Greenspan et al., 1949). Approximately 200 hypophysectomized female rats. 26 days old at surgery, were used 10 assay samples using a four-point assay procedure (i.e. 4 rats dose 2 doses). The assay endpoint measures increases in tibial epiphyseal plate widths atter four daily injections of hormone: it has a sensitivity of $1 \mu g$ and is specific for GH. Responses were compared 10 a bovine GH standard (1.j L mg) calibrated against a LSP standard: they are expressed in terms of an in-house preparation of rat $\mathrm{GH}(3.0 \mathrm{IU} \mathrm{mg})$.

\section{Proluan $(P R L)$}

PRL enzume immunoassay was done exactly as described previously (Signorella and $H$ ymer. 1984) using polyclonal antiserum (cross reactisity to $\mathrm{GH}$ $<0.3^{*}$ "at a dilution of $\left.1: 40000\right)$. Each sample was analyzed in duplicate at wo dilutions and the results are expressed relative to a rat PRL standard (B-7) kindly provided by the National Institute of Diabetes. Digestive and Kidney Disease and the National Hormone and Pituitary Program (Lniversity of Maryland School of Medicine).

PRL bioassay was done by the $\times b-2$ lymphoma cell assay originally described by Tanaka et al. (Tanaka et al., 19SO) and used routinely in our laboratory (Hymer et al., 1996b). This cell culture bioassay is specific for PRL and has a sensitivity of $0.2 \mathrm{ng} \mathrm{ml}$. It is based on the ability of PRL to cause division in a line of $T$-lymphocytes prepared from lymphomas of estrogenized rats.

\subsection{Follicle stimulating hormone (FSH). luteinizing hormone ( $\mathrm{LH}$ ), thyroid stimulating hormone (TSH) and adrenocorticotropic hormone (ACTH) assal's}

Radioimmunoassay kits for each of these pituitary hormones were kindly supplied by the $\mathrm{Na}$ - 
tional Institutes of Diabetes, Digestive, and Kidney Disease and the National Hormone and Pituitary Program (University of Maryland School of Medicine). All hormones were iodinated using IODO-GEN (Pierce Chemical, Rockville, IL): 2.5 $\mu \mathrm{g}$ of purified hormone and $250 \mu \mathrm{Ci}$ of $\mathrm{Na}^{125} \mathrm{I}$. Assay protocols were exactly as described in NIDDK technical notes. The following antisera and reference preparations were used: (1) rTSH; iodination preparation rTSH-I.9 (AFP-1308C), reference preparation rTSH-RP-2 (AFP-5153B), antisera anti-rTSH (C21381); (2) rLH: iodination preparation rLH-I-7 (AFP-9404B). reference preparation rLH-RP-3 (AFP-718;B). antisera anti rLH-S-10; (3) $\mathrm{rFSH}$; iodination preparation rFSH-1-S (AFP-11454B). reference preparation rRP-2 (AFP-462!B), antisera anti rFSH-S-11 (AFP-CO97ISS1: (4) hACTH used in heterologous assay (rat reagent not available): iodination and reierence preparation (AFP-632S031). antisera (AFP.2938C).

\section{Results}

\section{J. In titro hormone release in microgratity}

The total quantity of immunoreactive $\mathrm{GH}$, PRL, TSH. FSH, LH and ACTH released from the three different cell culture kits during 14 days in microgravity, relative to synchronous ground control cells, depended upon the frequency of media change and the particular hormone being measured (Fig. 3). Sometimes total hormone output from both ground and flight cultures was positively correlated with the frequency of media change, whereas in other cases feeding frequency had little effect. The total amounts of hormone released from either ground or flight cells varied over a wide range: i.e. $\sim 10$ micrograms (LH, FSH, TSH); 2-10 milligrams (PRL, GH); -100 nanograms (ACTH). Noteworthy flight-associated differences in total hormone release were (1) a $4 \times$ increase in $\mathrm{GH}$ release from unfed flight cells (Fig. 3A); (2) slight to moderate reductions in $\mathrm{LH}$ release from fed cultures (Fig. 3E); (3) small increases in $\mathrm{GH}$ and PRL release from cells fed four times (Fig. 3A and B); and (4) two-fold increases in total ACTH released from unfed cells or cells fed $4 \times$ (Fig. 3F).

\subsubsection{CCK \#1}

The kinetics of hormone release from cells fed 4 times sometimes revealed very different patterns in microgravity that were often dependent on feeding frequency and hormone type. For example. feeding cells 4 times during spaceflight resulted in approximately linear increases in rates of release of $P R L$ (Fig. 4D), FSH (Fig. SA) and ACTH (Fig. SG): however. the rates of release of PRL. FSH and ACTH from corresponding ground control cultures was different in each case. On the other hand. the rates of release of $\mathrm{GH}$ (Fig. 4.A) and TSH (Fig. 4G) were similar between ground and flight. $\mathrm{LH}$ release (Fig. $5 \mathrm{D}$ ) was initially $2-3 \times$ more from flight cells. but later in the mission these rates were the same as from ground cells.

\subsection{2. $C C K=2$}

These cells had their first medium change on day 9 followed by an immediate trypsinization procedure which resulted in cell detachment from the polycarbonate surface (based on microscopic observation in both ground and fight chambers). These were reinserted back into the same chamber and the culture allowed to continue for an additional 5 days. In every case. the rate of release of each of the six hormones was greater from ground cells after trypsinization (Fig. $4 \mathrm{~B}, \mathrm{E}$ and $\mathrm{H}$; Fig. $\Sigma B, E$ and $H$ ). However, in flight this release pattern was either similar (FSH. LH. TSH) or opposite (ACTH. GH, PRL).

\subsection{3. $C C K \# 3$}

These cells were left undisturbed over the entire experiment. The only changes in these flight cells were (a) $a x$ increase in GH release (Fig. 4C) and (b) a $2 \times$ increase in ACTH release (Fig. 5I).

When these same media from CCK's \#1,2 and 3 were assayed for their content of biologically active $\mathrm{GH}$ and $\mathrm{PRL}$, interesting flight-related differences were found, both in total amounts of bioactive hormone released and in the kinetics of that release. In terms of total bGH release, there was a $\sim 50 \%$ reduction from fed 

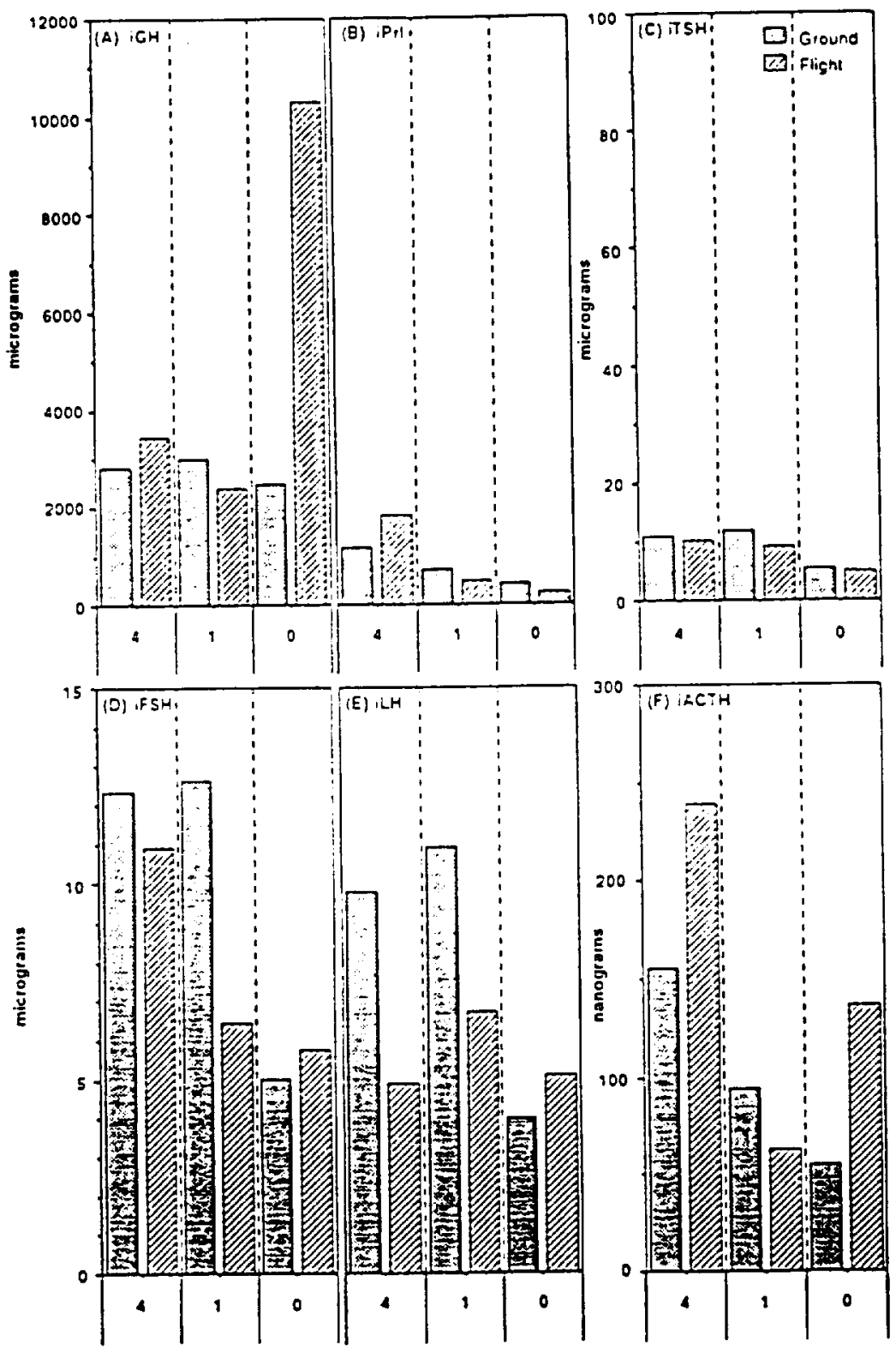

Fig. 3. Total release of immunoreactive (A) GH, (B). PRL. (C) TSH, (D) FSH, (E) LH and (F) ACTH from CCK \#1, \#2 and $\# 3$ in which culture media were changed 4,1 and 0 times, respectively. during 14 day's in microgravity. Note large difference in total quantities of hormones secreled (micrograms-nanograms).

flight cells and a doubling of hormone from the unfed flight cells (Fig. 6A). In terms of total bPRL released, the situation was approximately reversed. Thus, there was a $2.5 \times$ increase in total bPRL release from cells fed 4 times in microgravity while unfed PRL cells reduced bPRL output by one-half (Fig. 6B). The kinetic data relating to release of $b G H$ and $b P R L$ indicated (a) a large burst in initial bGH from ground (but not flight) cells in CCK \#1 (Fig. 7A); (b) no correlation between amounts of $\mathrm{iGH}$ and $\mathrm{bGH}$ measured in $\mathrm{CCK} \# 3$ flight media (cf. Fig. $4 \mathrm{C}$ vs. $7 \mathrm{C}$ ); and 
finally (c) a good correlation between iPRL and bPRL contents in CCK \# I flight media (cf. Fig. AD vs. $7 D)$.

\subsection{Analysis of released $G H$ by $H P L C$}

Each of the five samples obtained from CCK \#1. after fractionation by gel filtration chromatography. contained two peaks of iGH with very different apparent molecular weights (Fig. 8). One of these approximated to the known mass of $\mathrm{GH}$, viz 22 kd. The other had an apparent molecular weight $>2 \times 10^{5}$. Neither coincided with the OD $2 S 0$ profile which represents the major protein classes in the serum containing medium (Fig. 8. top). Generally speaking. the $\mathrm{iGH}$ elution profiles between the ground and flight samples

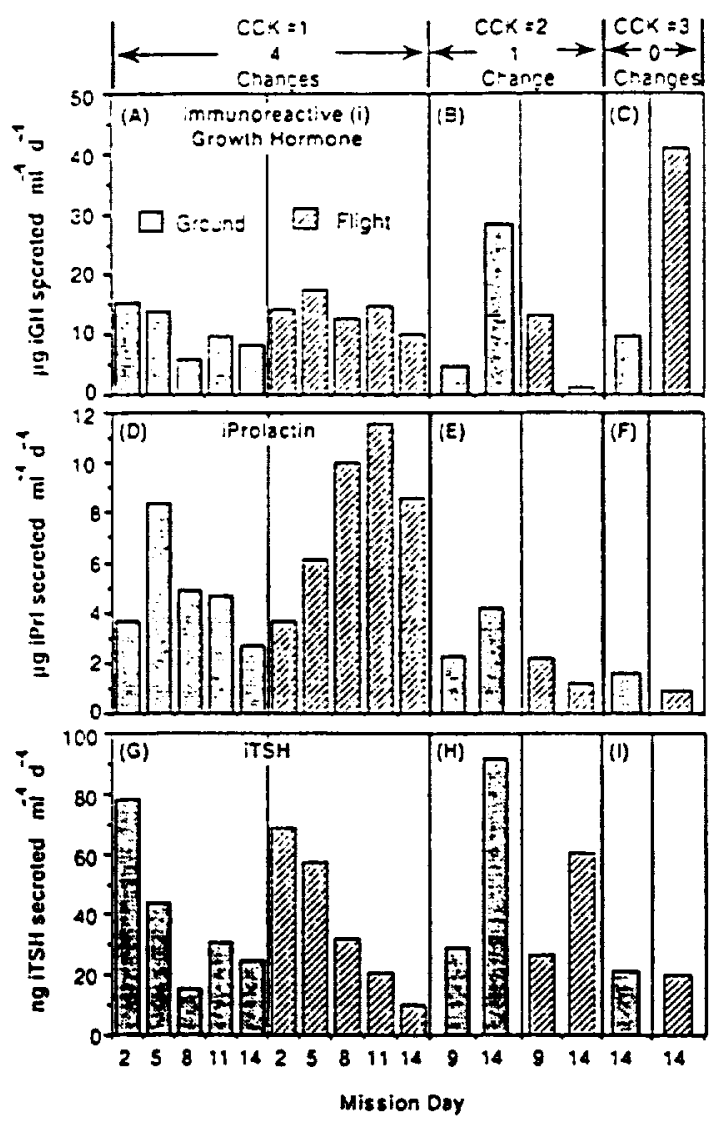

Fig. 4. Kinetics of release of $\mathrm{iGH}$, iPRL and iTSH from CCK's $1-3$ on earth and in microgravity.

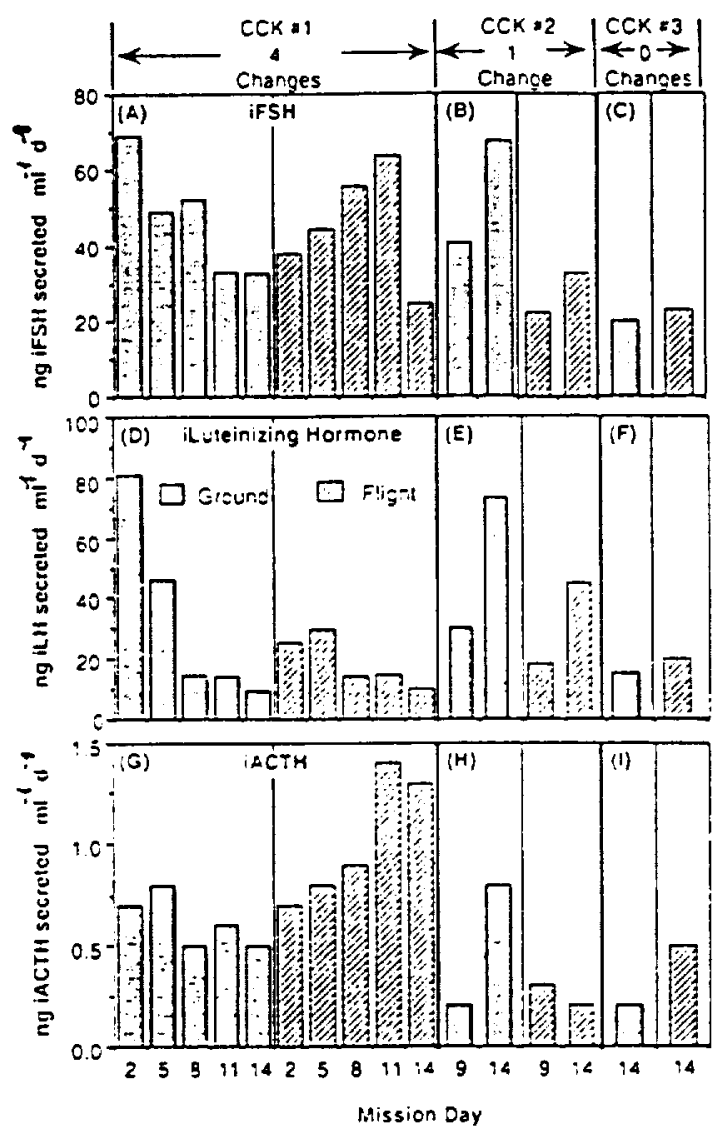

Fig. 5. Kinetics of release of iFSH. ILH and iACTH from CCK's $1-j$ on earth and in microgratity.

were similar. although flight samples tended to have more low molecular weight hormone. Finally, there was a progressive loss of high molecular weight $\mathrm{jGH}$ from both ground and flight samples as the time of culture increased. Total recoveries of $\mathrm{iGH}$ from both ground and fight samples after this step averaged $46 \pm 3 \%(n=$ 10). Of the recovered $\mathrm{iGH}$, a majority was in the lower molecular weight region (range 56-81\%).

After fractionation by anion exchange chromatography. each of the ten samples from CCK $\# 1$ contained a single peak of $\mathrm{iGH}$ which eluted from the column before the salt gradient began. A majority of the OD 280 material also eluted in this same region (Fig. 9. top). While the amount of iGH from the flight samples remained relatively constant throughout the culture. there was 
a progressive loss of $\mathrm{iGH}$ from the ground samples. The reason for this pattern is unknown. Recoveries of $\mathrm{iGH}$ from both ground and flight samples (i.e. fractions 2.3 and 4 ) after these steps averaged $88 \pm 10 \%(n=10)$ with no differences between ground and flight samples. Also shown in Fig. 9 (right column) are the biological activities of $G H$ in fractions 2 and 3 . assessed by the tibial line assay. Sometimes the patterns of $6 G H$ paralleled those of $\mathrm{iGH}$ (e.g. day 2. 5 and 14): other samples did not (e.g. day 11). It is especially interesting that the bGH concentrations were usually $2-7 \times$ greater than those measured by immunoassay. Recoveries of bGH from both ground and flight samples averaged $373 \doteq 80^{\prime \prime}$ i $(n=10)$ more than what was estimated to be present in the original sample of culture medium. This high recovery after ion exchange chromatography may result from removal of an inhibitor of bGH activity contained in the unfractionated sample.

The different profiles of $\mathrm{iGH}$ obtained after gel filtration and ion exchange chromaltography

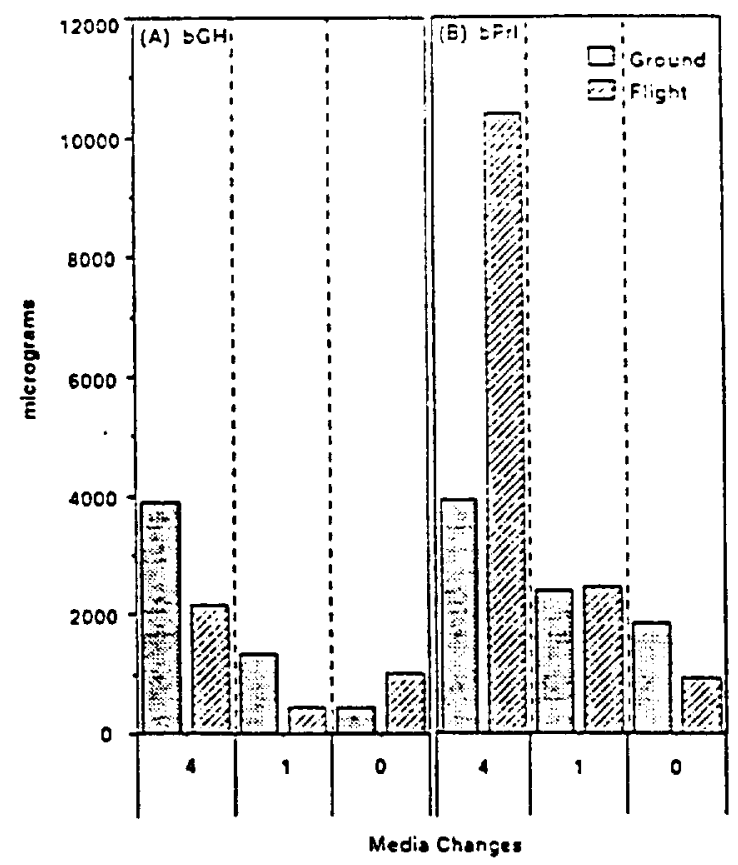

Fig. 6. Total release of bioactive $\mathrm{GH}(t)$ and bioactive $P R L$ (B) from cells in CCK \# $1-\# 3$ in which media were changed, 4. 1 and 0 times. respectively, during 14 days in micregravity.

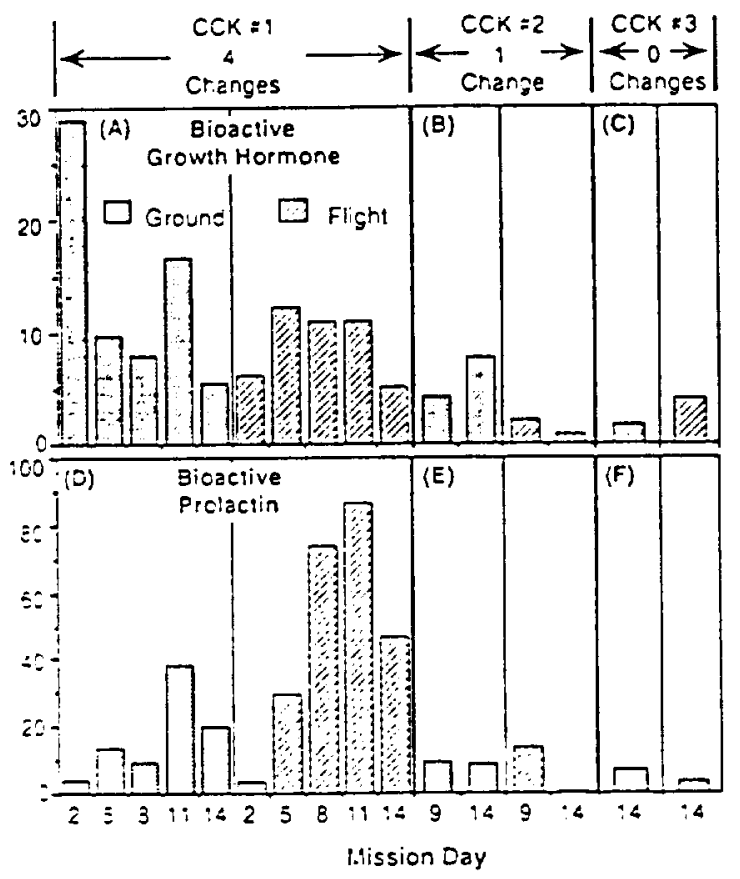

Fig. - Kinelics of release of bGH panels $(A-C)$ and $b P R L$ inurcis D-F) from the $6 \mathrm{CCK}$ 's. Note scaile difference.

prompted us to do a single rechromatography trial in which iGH molecules in fractions 2 and 3 were subsequently fractionated on the sizing coiumn. Because supplies were limited. this trial "as done only on the mission day $\$$ sample. The results show that what $\mathrm{iGH}$ was recovered (31\% ground: 11\% flight) had an apparent molecular weight in the range of $22 \mathrm{kd}$; none of the high molecular weight material in the original sample (Fig. S) was detected in this region after rechromatography (Fig. 10).

\subsection{Cell morphology}

Phase contrast microscopy of cells in the fight CCK's obtained within $3 \mathrm{~h}$ after Shuttle landing showed that live (phase bright), attached cells were present in all ground and flight chambers.

Considerable care and time was taken to photograph the cell growth and distribution patterns in each CCK from random areas at several mag nifications. The photographs show'n in Fig. 11 are taken at two different magnifications; they docu- 

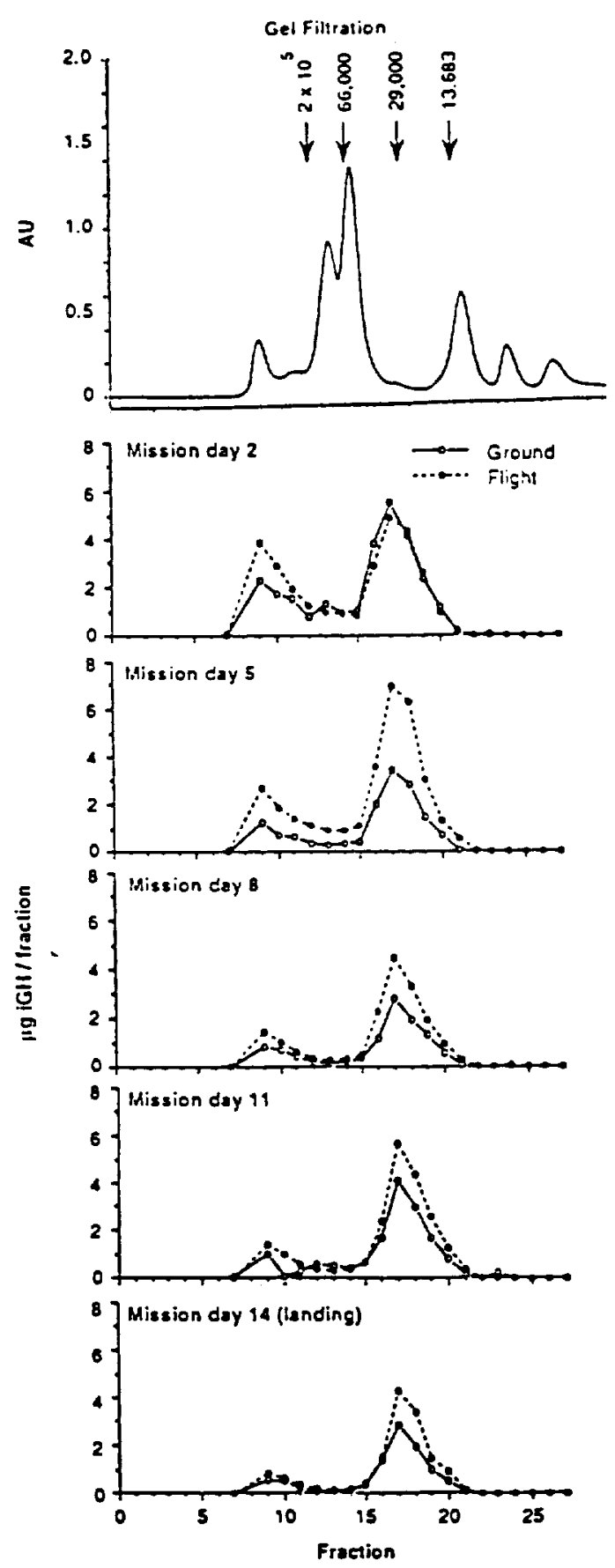

Fig. 8. Fractionation of culture media from spaceflown and ground control cells in CCK $\# 1$ by gel filtration HPLC. The optical density (OD 280) profile of serum proteins in the day.8 flight sample is shown in the top panel together with the elution position of standard molecular weight markers. OD profiles of all other samples were identical. ment attachment, cell viability, and growth patterns that are representative of the entire culture. At low magnification, the dominant feature of cells in CCK \#1 and \#3 was their clumping in CCK \#1, both ground and flight (Fig. $11 \mathrm{~A}$ and $B)$ and extensive clumping in flight $\mathrm{CCK} \# 3$ (Fig. 11F) but not ground CCK \#3 (Fig. 11E). Clumping of cells is easily seen because of scattered light which renders the cell clumps dark in the photomicrographs. Morphometry of these clumped areas from 3 different frames (entire photographic area) showed that these clumps occupied $10.9 \pm 1.0 \%$ (CCK $\neq 1$. ground): $12.6 \pm$ 2.6\% (CCK \#1. flight): $6.7 \pm 0.5 \%$ (CCK $\neq 3$. ground); and $62.6 \pm 4.4 " \prime \prime$ (CCK \#3, flight) of the total area. Cells in unclumped areas at higher magnification showed epithelial cell morphology that is typical for primary rat pituitary cultures except for one feature; i.e. total absence of fibroblast cell growth in unfed cultures from both flight and ground samples (cf. Fig. $11 \mathrm{G}$ and $\mathrm{H}$ is. $11 \mathrm{C}$ and $D$ ). Comparison of Fig. $11 C$ is. $11 D$ suggests that fibroblast grouth is greater in microgravity. but other photographs (not shown) do not. The cell images in flight CCK $\neq 2$. after Shutte land. ing, indicated that these anchorage dependent pituitary cells, after trypsinization on day 9 . reattached in microgravity sometime during the last 5 days of the mission (Fig. 12). These were more clumped than ground controls.

After Shuttle landing, our experimental design required cell removal from CCK \#1 and \#3 by irypsinization in order to do both cell image analyses as well as cell separation trials by continuous flow electrophoresis. The results of the electrophoresis trials are the subject of the companion report. In Fig. 13, we show the general features of trypsinized cells prepared from CCK's \#1 and $\# 3$ (both ground and flight) after immunocytochemical staining with a GH-specific antiserum. At this level of discrimination, there were no obvious differences in $\mathrm{GH}$ cells (darker cells in Fig. 13) or non-GH cells between any of the treatment groups except for a few ( < 10\%) "giant" single cells (or remains thereof) in flight cells from CCK \# 3. Image analysis of immunocytochemically stained $\mathrm{GH}$ cells indicated that some 

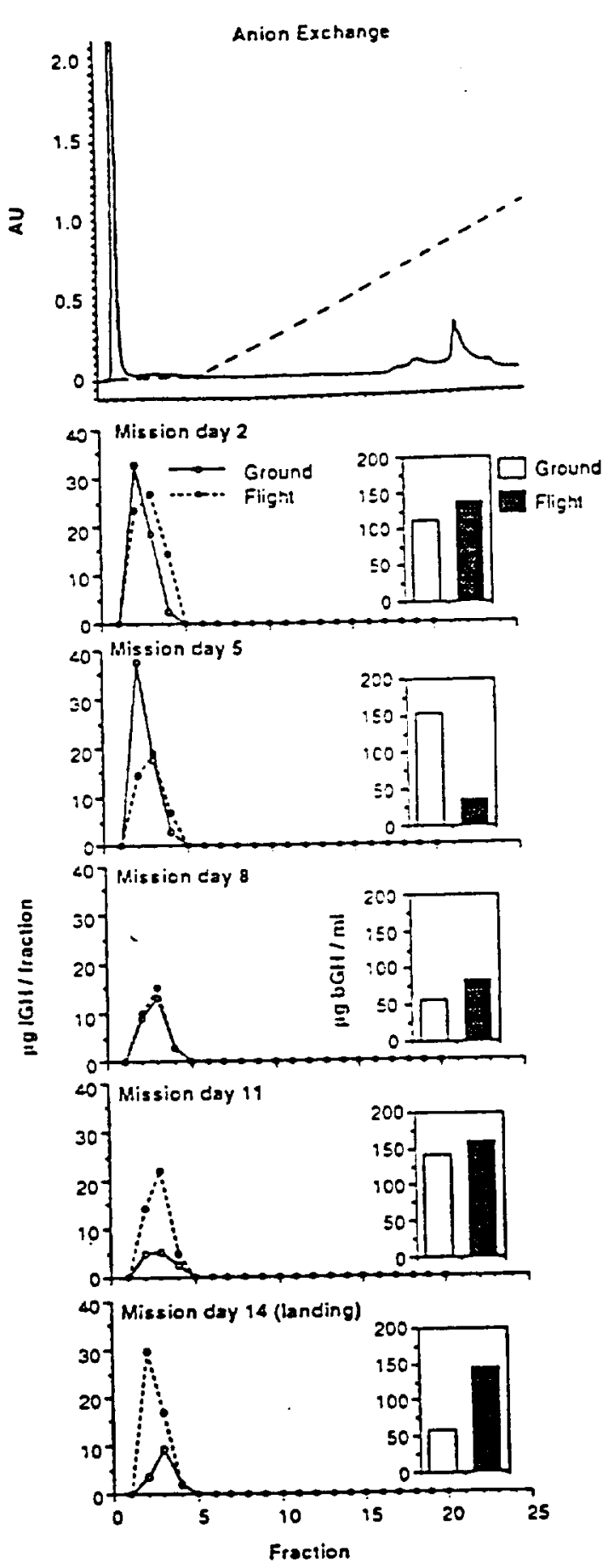

changes in the cytoplasmic areas occupied by $\mathrm{GH}$ had occurred: CCK \#3, ground $28.3 \pm 2.6 \%$, flight $16.5 \pm 2.1 \%,(P<0.001) ; \mathrm{CCK} \# 1$, ground $28.0 \pm 2.4 \%$, fight $21.8 \pm 2.1 \%(P<$ 0.05 ). The cytoplasmic area occupancy of $\mathrm{GH}$ in the initial cell suspension was $43.7 \%$.

In Fig. 14, we compare GH staining and light scatter profiles of all cells (a) contained in the initial population at the beginning of the experiment (launch minus 3 days, L- $\hat{\text { ) }}$ to cells (b) after removal from $C C K \# 1$ and \# 317 days later. The top panel in Fig. 14 shows the distribution pattern of nucleated cells after staining with propidium iodide. a red fluorescent dye that intercalates with DNA bases and thus differentiates dividing from quiescent cells by fluorescence intensity. The single symmetrical peak of red fluorescence in the initial cell preparation at L-3 days is typical for posi-mitotic primary rat pituitary cells (Fig. 14A). After the 17-day culiure, there was a small population (22\% ground. $11 \%$ hight) of cells from $\mathrm{CCK} \# 3$ with $>2 \mathrm{C}$ amounts of D.A (Fig. $1+B$ and $C$ ). These patterns probably represent dividing fibroblasts in these cultures. On the other hand. there was a considerable increase in the number of nucleated cells in CCK $\neq 1$ which had > ZC amounts of DNA: $65 \%$ ground. $45 "$ " Hight (Fig. $\mathrm{H}$ D and E). Because nany of these cells had a fibroblastic appearance after Shutile landing (Fig. 11). the most plausible explanation is that this increased red fluorescence signal represents fibroblast growth induced by changing culture media.

The middle panels of Fig. $(4 F-J)$ show the pattern of $\mathrm{GH}$ cell staining identified by the gate in the figure. The well defined peik of green fluorescence in the initial cell preparation is typical (Hatfield and Hymer. 1985) and show's that $40 \%$ of the total population contained GH. It is intcresting that the $\mathrm{GH}$ cell peak was better

Fig. 9. Fractionation of culture media from spacefown and ground control cells in CCK \# 1 by ion exchange HPLC. The optical density $(280 \mathrm{~nm})$ profiles of all 10 samples were identical to the one shown at the top of the figure. A majority of $O D 2 \$ 0$ material eluted from the column before the $0.6 \mathrm{M}$ $\mathrm{NaCl}$ gradient (donted line) began. The left panels show the distribution profiles of recovered iGH: all of it was recovered from fractions 2,3 and 4 . $\mathrm{GH}$ bioassays of hormone contained in fractions 2 and 3 (right panel) indicated that more bGH than iGH was present in these two fractions. Although fractions \# 2 and \# 3 were assayed separately, only the combined total of bGH is graphed. 


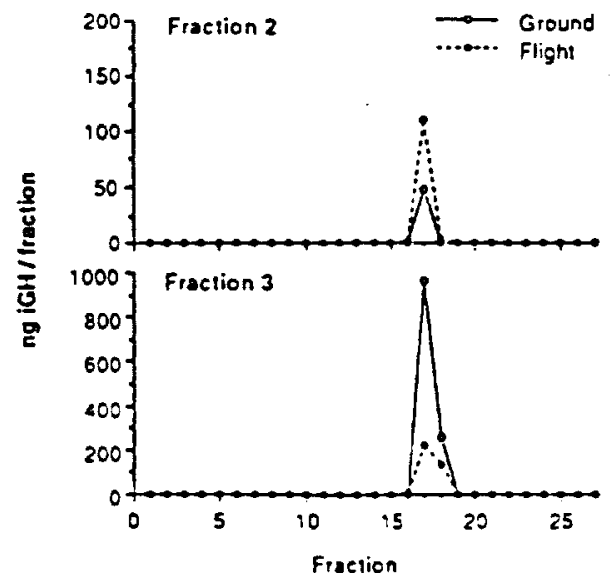

Fig. 10. Tho slep fractionation of cuiture media from CCK F 1. mission day \$. Fraction ? and 3 malurial. afler ion exchange HPLC (identical procedure :o that done in Fig. 91 uas followed by concentration and rechromalography by gel exclusion HPLC ridentical procedure :o that done in Fig. 8). The clution profile of the iGH shows that all of the recovered hormone had un apparent molesulur "eight of $-30 \mathrm{Kd}$. Vole that none of the higher molecular "sight $\mathrm{CGH}$ in another aliquot of this sample (Fr. $=9$. Fig. S) was present dfter rechromatography:

defined in both flight samples: however. the marker index (an index of the "brightness" of GH fluorescence determined by the ratio of voltages of stained to unstained cells) was $50 \%$ greater in unfed flight cells from CCK $\# 3$ (8.6 is. 5.7 ). but essentially no different in flight cells from CCK \#1 (6.0 vs. 5.8).

The lower panels of Fig. 14 show the forward angle light scatter (FALS) profiles in the various samples: these are indicators of cell size. Initially. $\mathrm{GH}$ cells were larger than the other hormone-producing cell classes; after culture and trypsinization, each of the four cell samples tended to have smaller GH cells. However media changes tended to result in increased mean FALS peak channel relative to unfed cells. This increase FALS signal from cells in CCK \#1 was also found in the non-GH containing cell peak as well.

\section{Discussion}

A primary objective of this spaceflight experiment was to determine if the frequency of cell feeding affected either the quantity or quality (activity) of hormones released from cultured primary rat anterior pituitary cells during 14 days in microgravity. There is litle doubt that this primary experimental objective was achieved. The versattility of the cell culture hardware. coupled with the ability to maintain temperature of the incubators on ground and space within $0.1^{\circ} \mathrm{C}$. enabled us to obtain meaningful resuits. To our knowledge. this is the first report to Jescribe the entire complement of profiles of the sir predominant hormones released from culured pituitary cells in micregrasity.

In order to fut the hormone release data into their proper context. it seems useful to make the following general statements concerning pituitury cell physiology in primary culture on earth. First. the intracellular concentration of $\mathrm{GH}$ in the pituitary is $S 0 \times$ greater than the next most prevalent hormone (Lewis. 1992). a fact which explains the relatively high amounts of $\mathrm{GH}$ in the culture media (e.g. Fig. 3). Second. chemical factors which gosern the relealse of anterior pituitary hormones from rat pituitary cells in earth culture are many and complex. For example, removal of the pituitary gland from chemical control of higher brain centers results in some loss of regulatory control of $\mathrm{GH}$ release (both positive and

Fig. 11. Phase contrast photomicrographs of cells in CCK \#1 and \#3 after the 17-day culture experiment. These micrographs uere taken within $3 \mathrm{~h}$ of Shuttle landing. Images shown are representative of the morphology of the tatal cell population in CCK \# $(A-D)$ and $C C K \# 3(E-H)$ at two magnifications (original photographs taken at $2 x$ magnification. punels $A$. $B$. $E$ and $F$; or $20 \times$ magnification. panels $\mathrm{C}, \mathrm{D}, \mathrm{G}$ and $\mathrm{H}$ ). The length of the micron bars is either $1000 \mu \mathrm{m}$ or $100 \mu \mathrm{m}$ for the low and higher magnification photographs, respectively. Differences in clumping between unfed cells in CCK \# 3 from ground (E) vs. fight (F) are obvious and they are representative of the entire field. The darkness of the image is calused by thickness of the cell clump and resulting light scatter. A higher magnification of the unfed cells from flighe CCK \#3 (panel F. arrow) is shown in Panel $\mathrm{H}$. Grouth of fibroblastic cells is obvious in fight CCK \# 1 (panel D); although not obvious. sells in ground CCK \# 1 (panel C): also had fibroblast grouth. Code: $C C K \# 1$. ground $(A$ and $C)$. fight $(B$ and $D) ; C C K \# 3$, ground ( $E$ and $G)$, fight $(F$ and $H)$. 

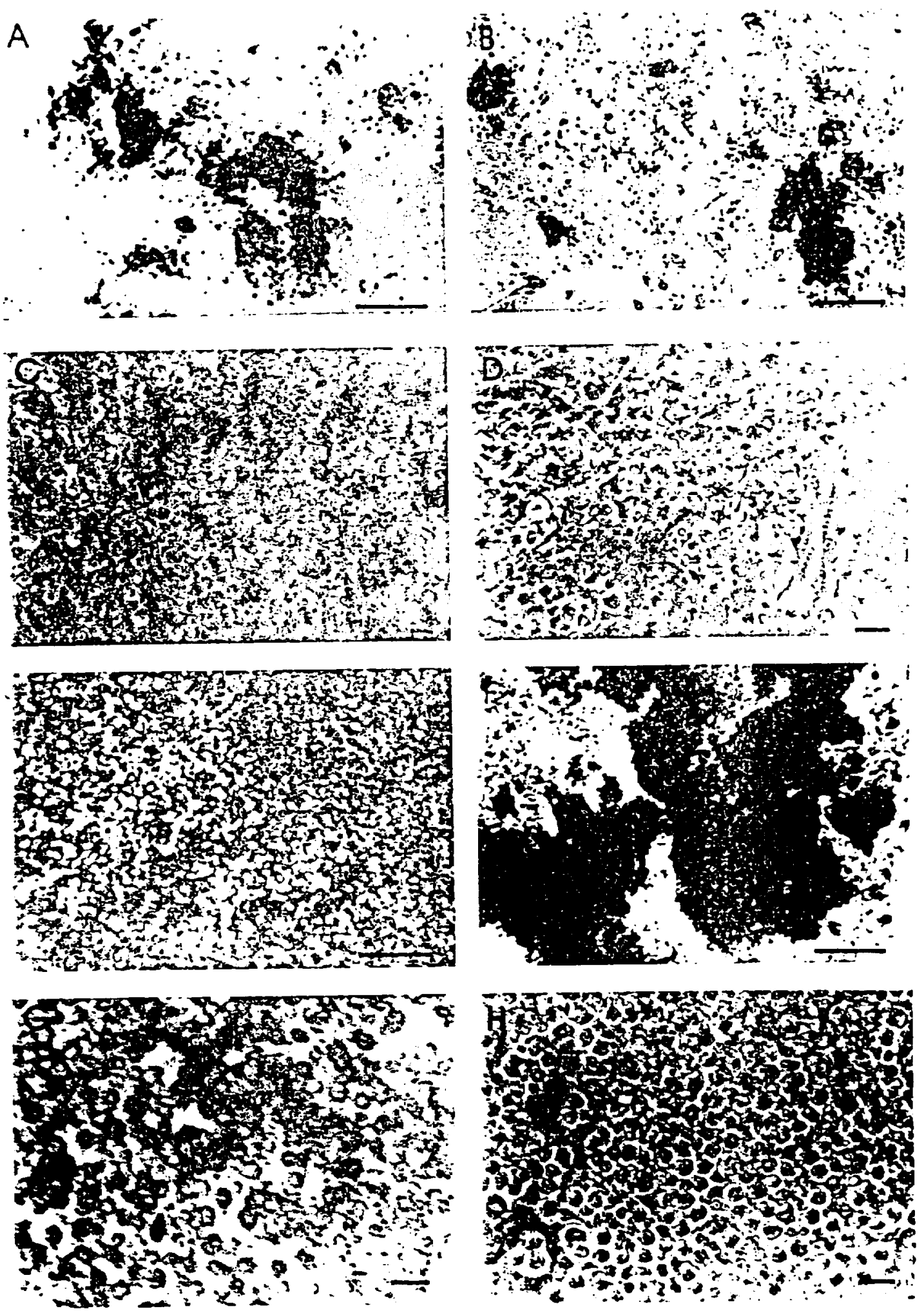

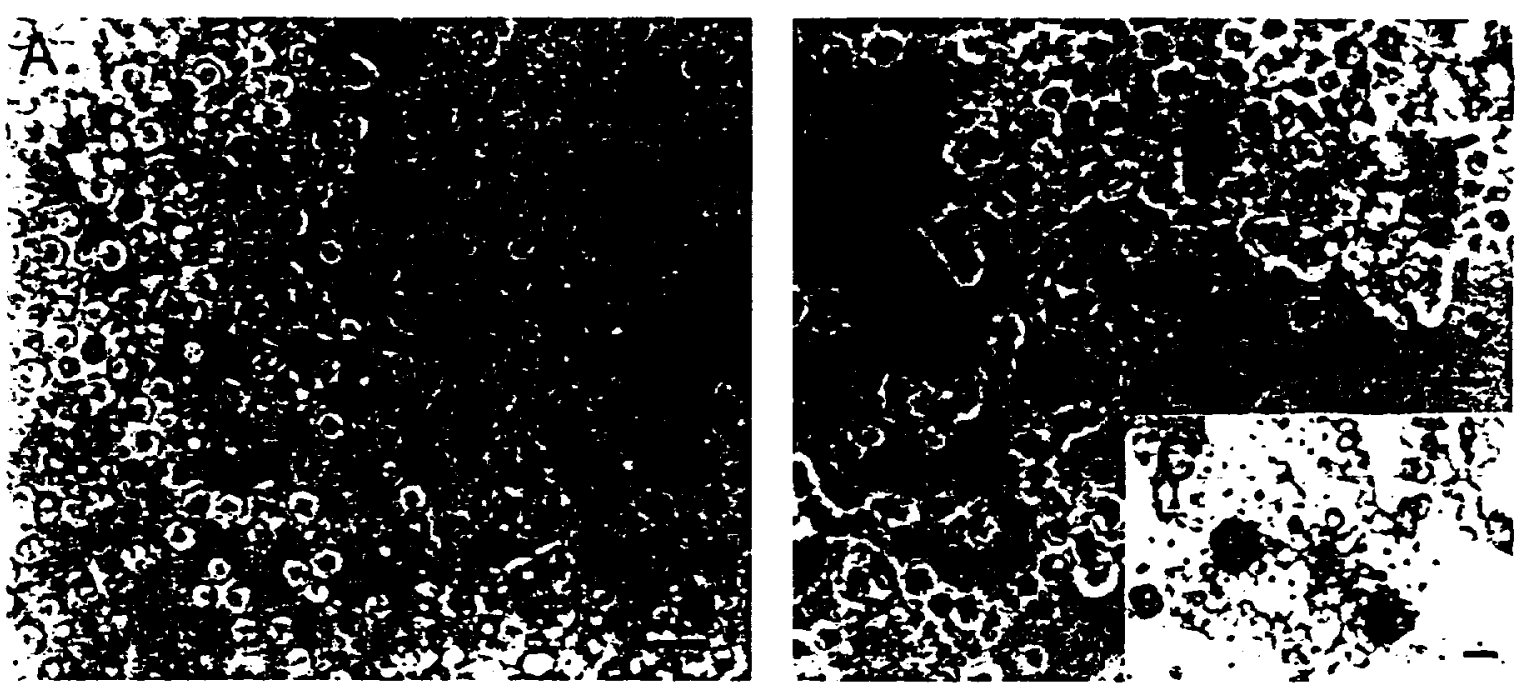

Fig. 12. Phase contrast photomicrographs of cells in CCK $=2$ atter the 17 day culture experiment. As shown in Fig. I. these ceils had been trpsinized and detached from the polycarbonate surface of ground CCK $=2$ (panel $A$ ) or flighi CCK $\# 2$ (panel B) in mission day 9 prior to reinsertion back into the CCK. Imanes shown are representative of their cell morphology seen after Shu:tie landing. Calls from flight were more elumped. Insert $(C)$ shows arsus of ageregation and chains of epitheicid cells. All micron $t a: 5$ in this figure are $100 \mu \mathrm{m}$.

negative) as well as remolal of a dominant inhibitory influence of dopamine from the brain on PRL release. The usual net result is "basal" release of preformed $\mathrm{GH}$ stores within $\mathrm{GH}$ cells and incrèased production (synthesis and release) of PRL in vitro (Wilfinger et al.. 1979). Third. many hundreds of primary pituitary cell culture studies have been done in the last 25 years. In spite of the obvious differences in experimental variables such as medium formulation, cell density. cell surface attachment. autocrine paracrine interactions. time of culture. feeding frequency. potency of released hormone. general physiology and species of the pituitary donor. one can make certain generalizations concerning hormone release in vitro (Houben and Denef. 1990). For example, (a) in the absence of brain peptides. the synthesis and release of PRL continues unabated while the ex-

Table 1

Pitituan factors which are thought to control hormone release via autocrine or paracrine interactions

\begin{tabular}{lll}
\hline Pituitury Factor & Autocrine (A) Paracrine (P) & Hormone System Alfecled \\
\hline ATP & A P & LH \\
EGF & A & ACTH. TSH \\
Neurotrophic Factor & A P & ACTH(?) \\
VIP IGF-1 & AP & PRL \\
GH GH receptor binding protein & A P & GH. PRL. LH \\
Activin & A & FSH \\
HPLC Fractios from Gonadotropes & P & PRL. GH \\
Pituitury Adenylate Cyclase Activating Peptide & P & GH \\
Nitric Oxide & A P & LH. GH \\
Calcitonin & A P & PRL \\
Substance P & A.P & LH \\
Arachidonic Acid & A.P & LH \\
\hline
\end{tabular}

- Taken from literature searches covering last 3 year period. Representative Studies. See (Houben and Denef, 1990) for recent review. 
Tuble ?

Correlation coefficients betucen total hormone released from CCK's $1-3$ vs. number of media changes*

\begin{tabular}{|c|c|c|c|c|}
\hline \multirow[t]{2}{*}{ Hormone } & \multicolumn{2}{|c|}{ Ground } & \multicolumn{2}{|l|}{ Flight } \\
\hline & Slope & $\Gamma^{2}$ & Scope & $\Gamma^{2}$ \\
\hline ¡GH & + & 0.17 & - & 0.36 \\
\hline bGH & + & 1.00 & + & 0.70 \\
\hline ¿PRL & + & 0.96 & $\div$ & 0.99 \\
\hline bPRL & $\div$ & 1.00 & $\div$ & 0.99 \\
\hline $\mathrm{LH}$ & - & 0.34 & - & 0.14 \\
\hline TSH & - & 0.32 & + & 0.66 \\
\hline FSH & - & 0.45 & $T$ & 0.99 \\
\hline $\mathrm{ACTH}$ & - & 0.98 & $\div$ & 0.61 \\
\hline
\end{tabular}

"See Figs. 4 and 5 for data used to calculate correlation coefficients by regression analysis.

tent of $\mathrm{GH}$ synthesis is usually more modest: (b) hormone sunthesis in the FSH. LH. TSH and ACTH cell systems does not occur to any appreciable extent unless the cells are properly stimulated in vitro: (c) paracrine interactions in the various hormone producing cell types take place as factors released from one type regulate hormone release from another (see Table 1); (d) evidence for autocrine feedback, i.e. decreased hormone release from a cell type caused by its prior release (e.g. PRL cells): and finally (e) the biological activity of a released hormone may not alway's be accurately reflected by immunological assays. This latter point is especially important because there is a growing awareness that hormone variants contained in the gland (variants resulting from, for example. aggregation, proteolytic cleavage. glycosylation, deamidation, phosphorylation of hormone molecules: Sinha, 1992) are also released in vitro. Some variants may go undetected in different assays.

How does the general pattern (i.e. directionality) of hormone release in microgravity compare to the usual behavior of earthbound cultured pituitary cells just described? Regression analysis of total hormone output, as a function of media change frequency, was used to address this issue (Table 2). If one assumes that a correlation of at least 0.7 represents a strong tendency towards an effect, one can conclude that the overall patterns of release of some of the six hormones studied are not different in microgravity. Stated another way, the more frequently media are changed, the more $b G H$, iPRL and bPRL is released from both ground and flight cells. However, no such correlation is apparent for $\mathrm{iGH}, \mathrm{LH}$, and TSH from either ground or flight cells. In the case of FSH, there was excellent correlation betw'een hormone release and cell feeding in flight, but not ground. In the case of $\mathrm{ACTH}$, the correlation was high

Table 3

Parameters which suggest that microgravity-cell feeding interactive effects exist (top) relative to synchronous ground controis or do not (bottom)

\begin{tabular}{|c|c|c|}
\hline \multirow[t]{2}{*}{ Parameter } & \multicolumn{2}{|c|}{ Number of media changes } \\
\hline & 0 & 4 \\
\hline $\begin{array}{l}\text { (1) Epithelial cell } \\
\text { clumping }\end{array}$ & $\uparrow$ & $\begin{array}{l}\text { Sot different } \\
\text { (XD) }\end{array}$ \\
\hline $\begin{array}{l}\text { (2) Cell size (non-GH } \\
\text { cells) }\end{array}$ & $N D$ & $i$ \\
\hline \multicolumn{3}{|l|}{$\begin{array}{l}\text { (4) Total GH release } \\
\text { pattern }\end{array}$} \\
\hline$\cdot \mathrm{jGH}$ & $\uparrow(314 \%)$ & $i(2-2+10)$ \\
\hline - $\mathrm{bGH}$ & $i(135 \%)$ & $!(45 n)$ \\
\hline \multicolumn{3}{|l|}{$\begin{array}{l}\text { (5) Xon-GH release } \\
\text { patterns (total) }\end{array}$} \\
\hline - iPRL & $+(45 \%)$ & $i(5 ; \%)$ \\
\hline - bPRL & $+(50 \%)$ & $\uparrow(165 \%)$ \\
\hline • iLH & $\uparrow(28 \%)$ & $1(50 \%)$ \\
\hline 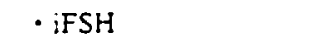 & $i(10 \%)$ & $1(10 \%)$ \\
\hline - $A C T H$ & $\uparrow(80 \%)$ & $i(200 \%)$ \\
\hline (1) Fibroblast grouth & ND (none) & ND (extensive) \\
\hline \multicolumn{3}{|l|}{ (2) $\mathrm{GH}$ cells } \\
\hline $\begin{array}{l}\text { - Cytoplasmic area } \\
\text { occupancy }\end{array}$ & $\downarrow(41 \%)$ & $1(22 \%)$ \\
\hline $\begin{array}{l}\text { - Marker index } \\
\text { (3) Non-GH release } \\
\text { pattern (total) }\end{array}$ & $i(51 \%)$ & $\uparrow(4 \%)$ \\
\hline iTSH & ND & ND \\
\hline (4) GH molecules & & \\
\hline $\begin{array}{l}\text { - size } \\
\text { - ion exchange }\end{array}$ & - & ND $(\downarrow$ High $\mathrm{MW})$ \\
\hline $\mathrm{iGH}$ & - & Fluctuating \\
\hline $\mathrm{bGH}$ & - & Fluctuating \\
\hline - GH binding protein & - & $?$ \\
\hline
\end{tabular}



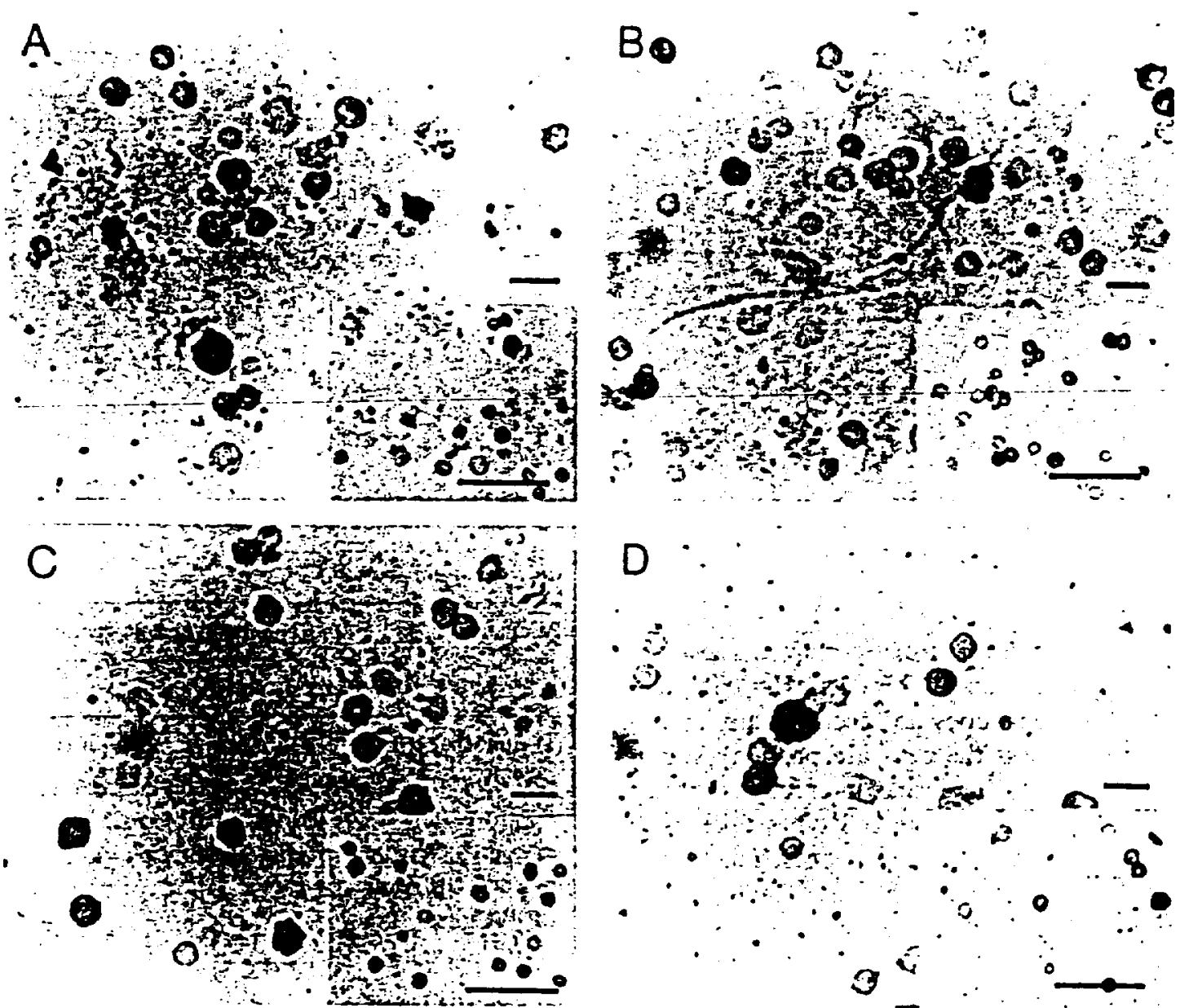

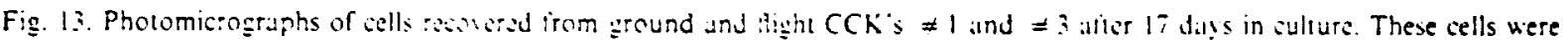

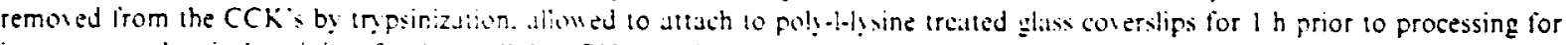

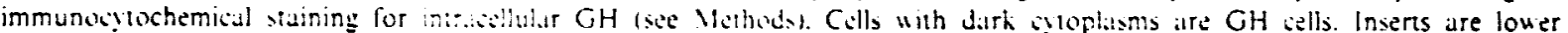

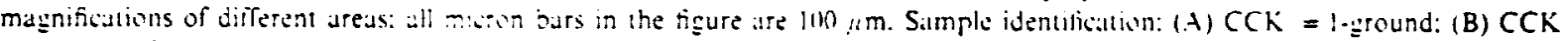

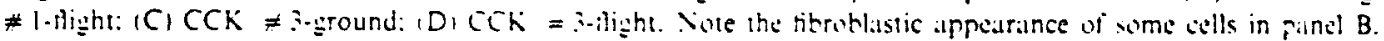

from ground. but not flight cells. As shown in Table 2. the directions of change. reflected by slopes of the regression lines. "Iere actually opposite in sign between ground and flight in two instances (iLH. iGH). These findings obriously refiect the complexity and specificity in behavior of hormone release from this heterogeneous cell system.

These generalizations should not be interpreted to indicalte that the quantity or quality of the hormone is unaffected by feeding frequency in microgravity. Indeed. some microgravity-specific changes are clearly evident in flight cells as reflected in (1) a large increase in $\mathrm{GGH}$ and $\mathrm{ACTH}$ release from unfed cells: (2) moderate reductions in LH and FSH release from fed cells: (3) modest increases in $\mathrm{iGH}$ and $\mathrm{iPRL}$ release from cells fed four times: and finally (4) a large increase in bPRL release from cells fed four times in spaceflight.

What might account for these microgravity-associated changes in hormone release? The most obvious operational difference between cells in CCK \#1 vs. \# 3 is the frequency of medium replacement. Lack of feeding will result in a consistently quiescent environment that cells in flight 


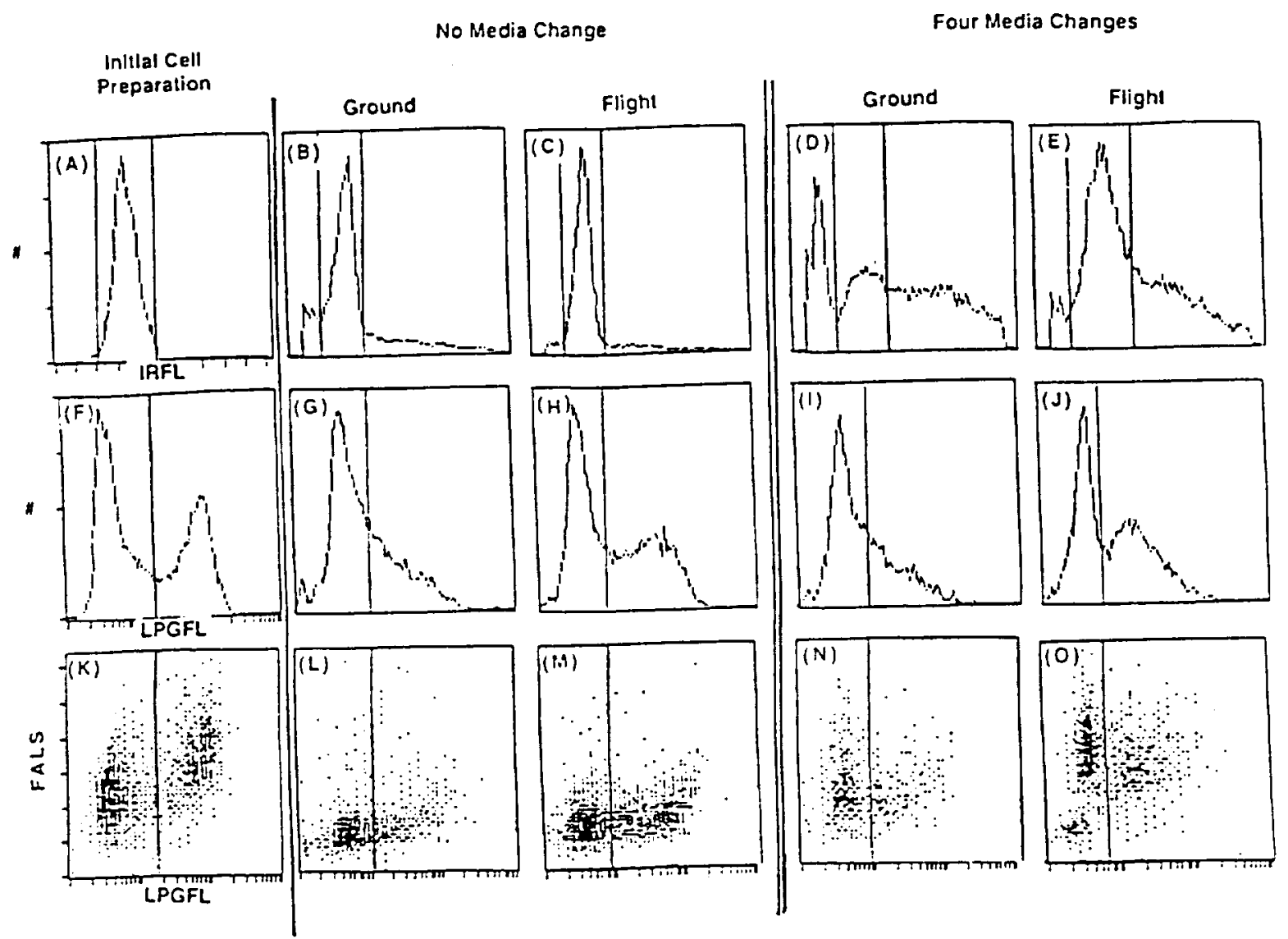

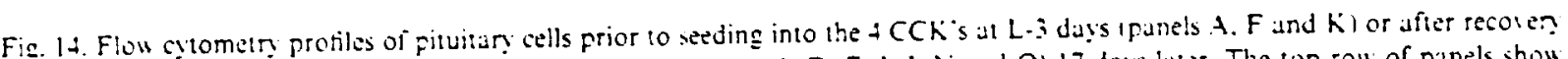
from CCK $=3$ (panels B. C. G. H. L and M) or CCK $\neq 1$ (panels D. E. I. J. N and O) 17 days later. The top row of panels show profiles red fluorescence after stuining with propiditm iodide. a DVA marker which indicates ihe concentration of D.NA cell. Increased fluorescence in cells from CCK $\# 1$ may reflect fibroblast grow th and division in this sample. The middle panels show $\mathrm{GH}$-stained cells (green fluorescence). The profile in the initial cell sampie (panel $F$ ) is apical and differentiates stained from unstained cells. Note that the $\mathrm{GH}$ staining profiles uere better defined in the dight samples (panels $\mathrm{H}$ and $\mathrm{J}$. The lower panels show the forward angle light scalter (F.tLS) patterns of unstained (arrow. punel $K$ ) and GH stuined cells before and after flight.

CCK \# 3 must have experienced. The excellent theoretical analysis by Albrecht-Buehler (Albrecht-Buehler, 1991) considers possible consequences of such a quiescent environment on mammalian cell function in microgravity. How might such an environment actually result in the differences found in our study? To address this problem. we searched for results that were either opposite in character (or very different in magnitude) between CCK \#1 vs. \#3, because these presumably would be of most interest in sorting out microgravity-feeding frequency interactions. Differences meeting these criteria are given in Table 3 (top); those which do not are shown in
Table 3 (bottom). Because evidence for the importance of autocrine paracrine interactions in regulating hormone release from anterior pituitary cells continue to grow (Table 1), and because decreased microconvection in pituitary cell cultures in spacefight could conceivably impact on these types of interactions, it seems reasonable to postulate that some of the changes we have found in this experiment can be explained in part by the models offered in Fig. 15 and 16.

An example of hormone release from a cell class controlled by an autocrine feedback loop is the PRL cell. Walker's laboratory has shown that PRL released from a cell in culture can feedback 


\section{PROLACTIN CELL IN VITRO}

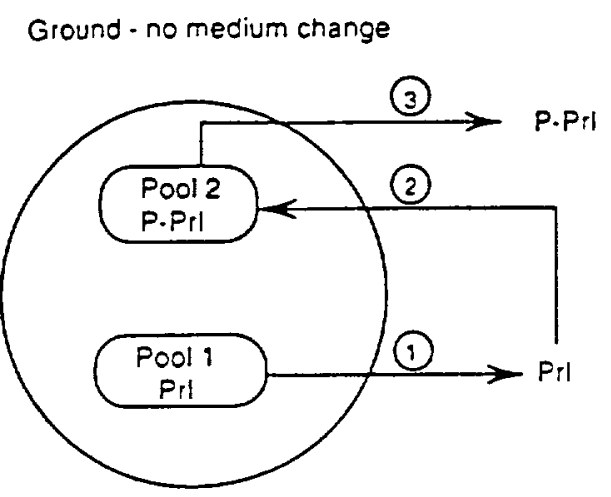

Flight - no medium change

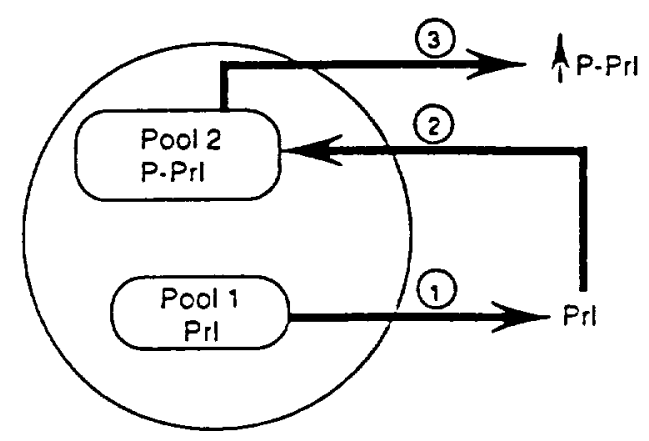

EVENTS IN MICROGRAVITY

(A) Prl cell 'senses" new environment: A Prl buitup around celi

(E) $\frac{P \cdot P_{11}}{P_{n 1}}>$ ?

(C) Restii: Inctivity of Fil in Nb.2 cell bicessey

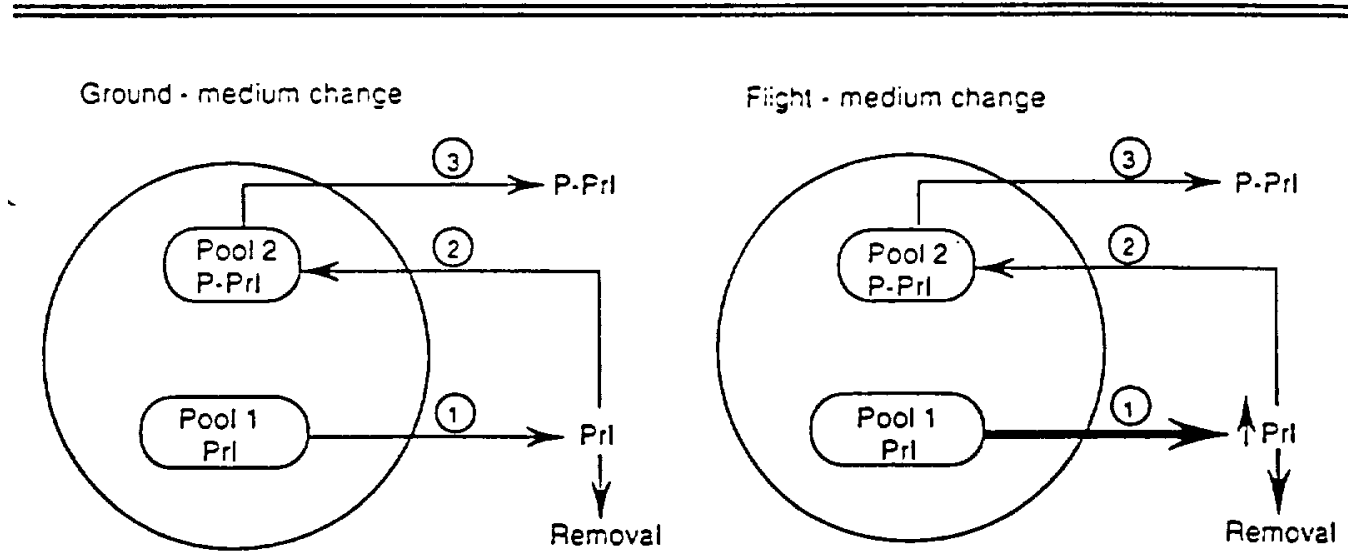

EVENTS IN MICROGRAVITY

(A) Prl cell "senses" new environment

(B) Non-phosphorylated Prl removed via medium change

(C) Y Aulocrine feedback

(D) $\frac{\mathrm{P}-\mathrm{Prl}}{\mathrm{Prl}}<1$ Fesult; $\mathrm{f}_{\text {Activity }} \mathrm{P} \mathrm{Prl}$ in Nb-2 cell bioassay

Fig. 15. An autocrine feedback model for bPRL release.

on itself via an autocrine loop; ultimately this modifies the molecular form of the hormone (in this case its degree of phosphorylation) via posttranslational control mechanism(s) (Walker, 
$\mathrm{CCK} \# 3$

$$
\text { GROWTH HORMONE CELL IN VITRQ }
$$

Ground - no medium change

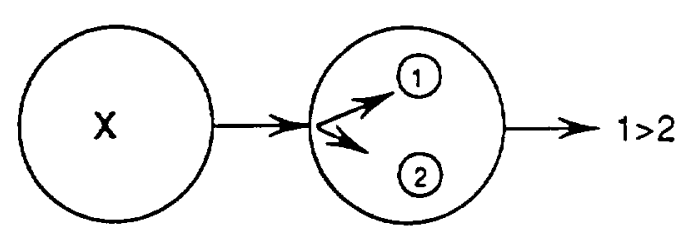

EVENTS IN MICROGRAVITY

(A) Extensive cell clumfing promotes Aparacrine in:eaction

(B) Release of iGH favcied by factor from cell $X$
Pool $1=i G H$

PoOl $2=b G H$
Flight - no medium change

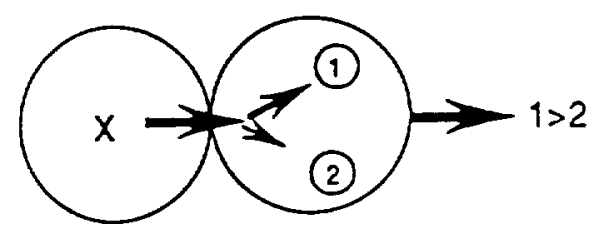

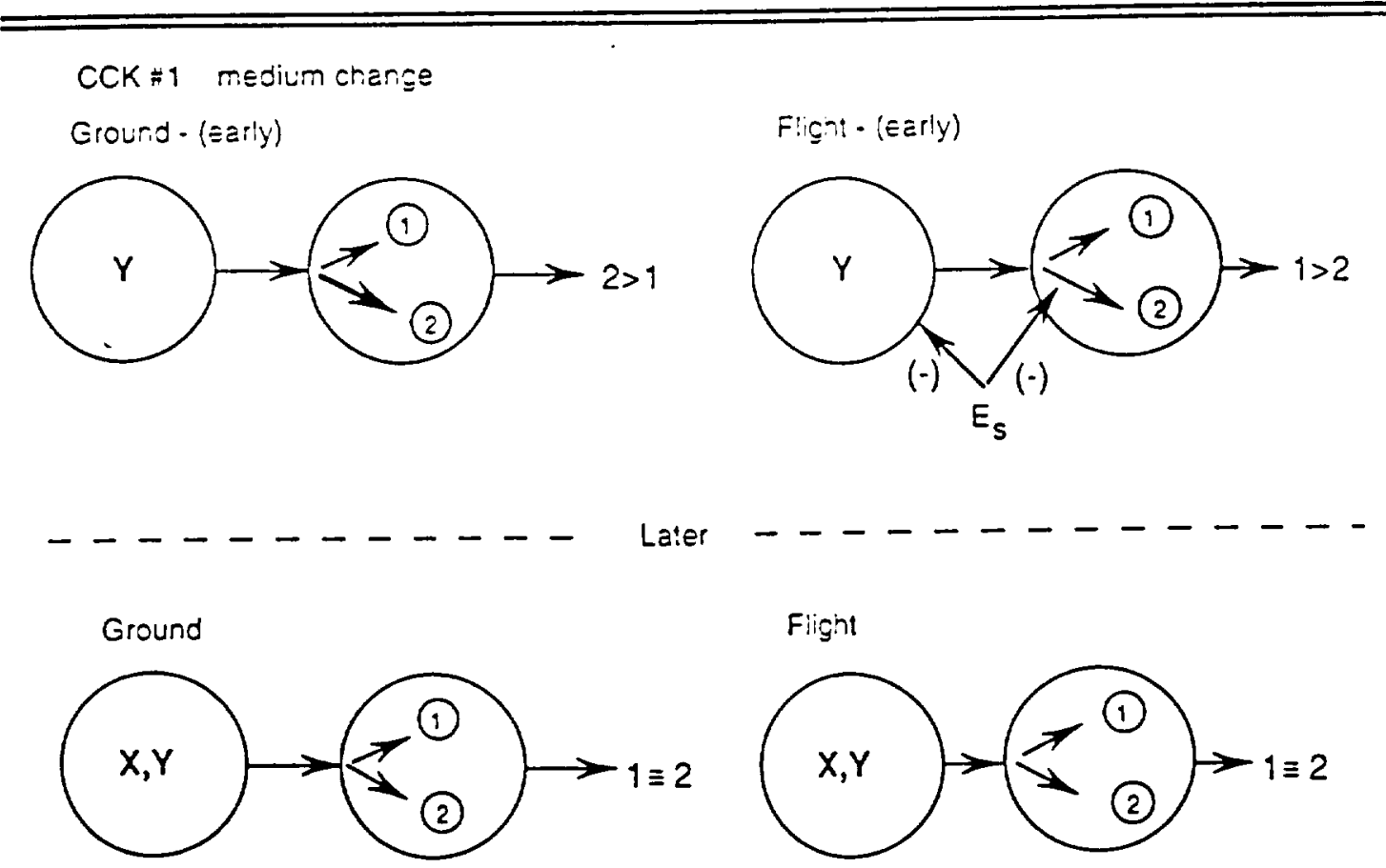

EVENTS IN MICROGRAVITY

(1) Early in flight "Entry stress factor" suppresses release from pool 2

(2) Later, cells achieve new set point.

Fig. 16. A paracrine feedback model for bGH release. 

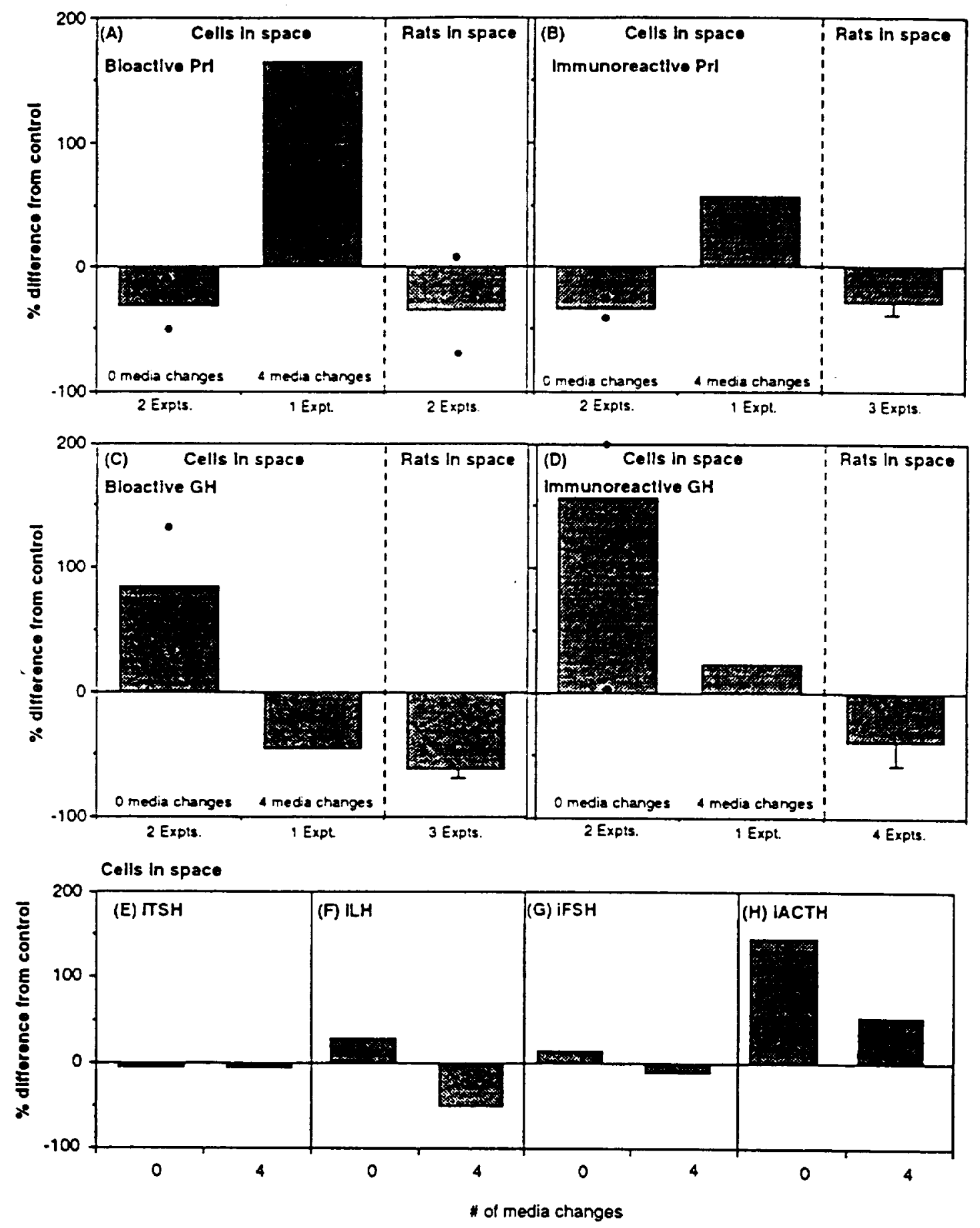
1994). We suggest that PRL cells in CCK \# 3 in microgravity have augmented autocrine feedback resulting directly from an increased accumulation of PRL around the cell. As suggested by the model (Fig. 15). the extracellular fluid environment might accumulate molecules having a ratio of phosphorylated PRL (p-PRL) PRL $>1$. Because $p-P R L$ is less active in the $N b-2$ cell bioassay (and indeed can neutralize the activity of non phosphorylated PRL in this assay in a ratio of 1 phosphorylated variant $10 \quad 10$ native molecules (Wang and Walker. 1993). the final result would be decreased activity of bPRL in media from flight $\mathrm{CCK} \neq 3$. On the other hand. autocrine feedback in CCK $\neq 1$ would be less as a consequence of medium changes: this might result in a p-PRL PRL ratio of $<1$. In turn. increased activity of PRL in tight $C C K \# 1$ media would result as suggested by the model and the actual data (Fig. 6).

How paracrine interactions might be affected by the microgravity environment has suggested by results of our $\mathrm{GH}$ cell studies on earih and in space. For example. we have shown that approxjmately one-half of all $G H$ cells have densities $>1.070 \mathrm{~g} \mathrm{~cm}^{2}$ (Snyder et al.. 1977). Functional and biochemical differences in $\mathrm{GH}$ molecules released from these dense $\mathrm{GH}$ cells in vitro include (a) greater amounts of disulfide-linked oligomeric forms (Farrington and Hymer. 1990) and (b) greater biological activities in the hypophysectomized rat tibial line assay (Hymer et al., 1981). A convincing demonstration that paracrine interactions can affect the quantity and bioactivity of $\mathrm{GH}$ released from cells in microgravity was obtained in our passive 8 -day pituitary cell culture spaceflight experiment in 1992 (Hymer et al., 1996a). In that experiment. we showed that release of bGH from dense $\mathrm{GH}$ cells, in isolation, was reduced by $-50 \%$ relative to ground control cells. However. in mixed cell cultures. Output of bGH in microgravity uas significantly increased. This finding established that some factor(s) released from cells in the less dense cell population stimulated the dense $\mathrm{GH}$ cells to release more bGH in microgravity than on earth. The identity of the paracrine stimulatory molecule(s) remains elusive: as suggested by the list in Table 1 . it could be GH itself (an isoform?); a GH receptor binding protein made within the pituitary gland or another factor (orher hormones?). How might the feeding frequency of $\mathrm{GH}$ cells in microgravity affect paracrine regulators and ultimately the quality of released $G H$ ? The massive cell clumping seen in flight CCK \#3 (Fig. 11) could enhance paracrine interactions leading to increased release of bGH (Fig. 6). Although decreased conrection in fight CCK $\ddot{\#} 1$ experienced during the $\therefore$-day interials between media changes might be expected 10 minimize effectiveness of paracrine interactions (Fig. 16). the kinetic data show that the most important effect occurred on day 2: the cther four samples from boih ground and flight contuined approximately the same amount of bGH. Other additional mechanisms must certainly be involved (e.g. "stresses" associated with launch) to account for changes we find in hormone release. As suggested by the model. several paracrine faciors may be involved.

IIe have bein fortunate to be able to do two pituitary cell culture experiments in space as well as three experiments using pituitary cells from spaceflown rats. Their focus has been exclusively on GH and PRL. It is interesting to compare the results from these in vitro is. in vivo approaches, but given variability in experimental design (e.g. length of time in microgravity) the comparisons can of course be taken only so far. Nevertheless, comparisons of bPRL (Fig. 17A) and bGH (Fig. $17 B)$ release are interesting. Clearly, four media

Fig. 17. Comparison of bPRL (A and $B$ ) and $b G H(C$ and $D$ ) releuse from either mixed pituitary cell cultures in microgravity or from mixed pituitury cell cultures prepared postflight from spacefoun rats. The two experiments using passive (unfed) cell culture were in 1992 (STS-46, 8 day's in microgravity) and in 1994 (STS-65: 14 days in microgravity, CCK \# 3, this report); the single experiment employing four media changes was also STS-65. The ihree experiments using spaceflown rats were SL-3 (7 days); COSNOS 1987 (13 days) and COS.1OS 2044 (14 days). Release of bPRL from spacetiou'n rats was only done on the 2 COSMOS fights. Dots represent values of individual experiments; error bar $=$ S.E.M. Similar comparisons between the release of immunoreactive TSH. LH, FSH and ACTH from fed and unfed cultures. relative to ground controls, are shoun in panels E-H. None of these latter hormones were measured in cells from our spaceflown rats (Hymer et al.. 1992; Grindeland et al., 1987). 
changes in low gravity result in very different release profiles of bioactive PRL and $G H$. The

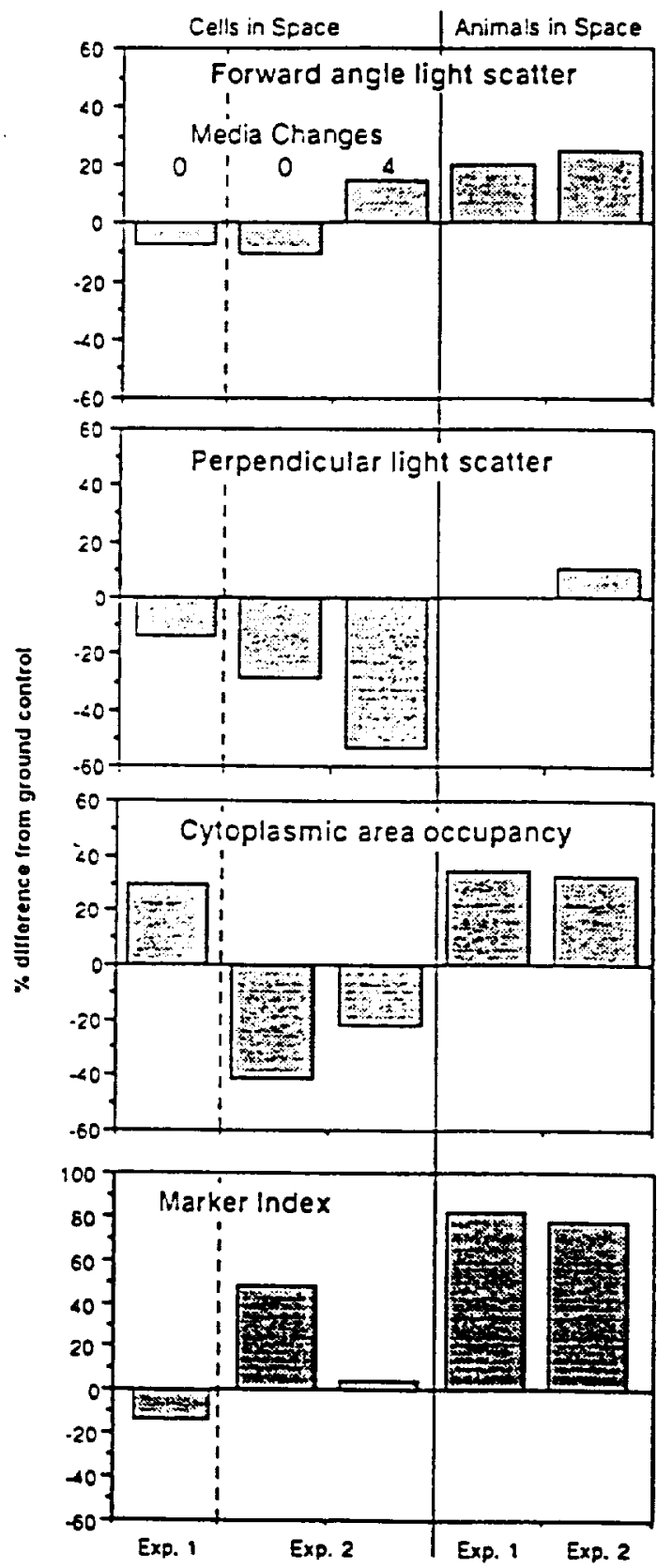

Fig. 18. Biophysical parameters of $\mathrm{GH}$ cells after cell culture in microgravity (left panel) or after their postflight preparation from spacefloun rats (right panel). Cell culture: Exp. \#I was STS-46: \#2 was STS-65 (this repon). Rat spaceflight Exp. \#1 was COS.MOS 1887; Exp. \# 2 was COSMOS 2044. fact that four media changes in flight yielded bGH changes that were of a magnitude similar to that from cells of the intact animal would tend to argue for better "physiological fidelity" when culture media are changed. However, that same idea does not seem to apply for bPRL. Once again. specificity of microgravity effects in terms of different hormone release behavior becomes evident. Although less complete, the summary data in panels $\mathrm{C}-\mathrm{F}$ of $\mathrm{Fig} .17$ also show different release patterns of TSH, LH. FSH and ACTH in microgravity as a function of cell feeding.

The "negative" information in Table 3 (bot. (om) is also important in the sense it shows that some of the cellular mechanisms at play in the ground cultures are also operational in flight. These include the finding (1) that pituitury cells were able to reattach to the surface of the CCK \#2 after trypsinization; these reattached cells continue to release hormones. often at a comparable rate to the ground control cells: (2) that the mechanism(s) which promote fibroblast growth in fed cultures on earth also appear operable in microgravity: and (3) that the molecular characteristics of the released $\mathrm{GH}$, at cur current level of biochemical analyses. are not different between the two groups. We are not the first to show that anchorage dependent cells can reattach in microgravity (Morrison. 1994). Moreover. our previous data. while not as extensive as those collected in this experiment. also failed to find significant microgravity-related changes in apparent size of released $\mathrm{GH}$ molecules (Hymer et al., 1996a). If molecular changes do in fact occur, they will obviously require probes different from the ones used to date. However, we do consider the preliminary data regarding the behavior of released $\mathrm{GH}$ from the mission day-8 sample after rechromatography interesting and potentially important. We favor the interpretation of these data (Fig. 10) to indicate that a portion of secreted $\mathrm{GH}$ is bound to carrier. However, we cannot discount the possibility that this high molecular weight $\mathrm{GH}$ represents aggregated hormone. If this idea is valid it would mean that production of this molecular complex decreases as the culture period progresses. Future experiments directed toward this aspect of the problem may prove worthwhile. The nature of 
bGH molecules which are released from the pituitary gland of the human and rat has been a topic of much interest in our laboratories for many years. The fact that recoveries of tibial growth promoting activity after the gel filtration step ranged $40-80 \%$ of that measured in the original culture fluid, but ranged $200-400 \%$ after ion exchange chromatography suggests that an inhibitory material may be co-released which obviously would result in an underestimation of the actual concentration of $b G H$ in the unfractionated sample.

Data from this experiment are internally consistent with the Albrecht-Buetler's hypothesis that extracellular medium quiescence represents the primary gravisensing mechanism which will lead to altered hormone release (Altrecht-Buehler, 1991). What are likely secondary biophysical changes inside the cell that would be called into play after this primary gravisensing event occurred? The four cellular markers studied in $\mathrm{GH}$ cells thus far (Fig. 1S) yield results that are interesting. but not definitive. Changes in cell size (FALS) might indirectly reflect the changes in tensional integrity of the cyoskeletal network. Furthermore. the different character of the $\mathrm{GH}$ fuorescence intensity measurements in some of the in vitro vs. in vivo situations may reflect differences in intracellular packaging such that epitopes on the GH molecules are exposed to a greater or lesser degree in spaceflown cells. Such changes would manifest themselves as differences in fluorescence intensity. The other measurements represented in Fig. 18. viz cytoplasmic area occupied by $G H$ and perpendicular light scatter signals, bear on the distribution of the intracellular secretory granules (Hatfield and Hymer, 1985). It is not obvious how they correlate with the hormone release data.

Operations in biotechnology laboratories on earth are routinely coupled. one process with another. This spaceflight experiment successfully demonstrated that it is possible to change cell culture fluids in sterile fashion: freeze the spent medium; prepare a fresh trypsin solution in microgravity; trypsinize and reseed cells - all operations that will certainly be required on a routine basis when the Space Station is operational.

The general conclusion that anterior pituitary gland function is affected in low gravity is inescapable: so too is the conclusion that a complete definition of the underlying cellular and molecular mechanisms will require extensive use of cell culture technology in microgravity. It would seem that any future pituitary cell culture experiment in microgravity should be tailored to meet the unique behavior of the primary hormone system being studied. When mechanisms are better understood, they should prove of use in studies aimed at defining countermeasures to physiological changes encountered during manned spaceflight. At the same time. they can serve the dual role of application of a unique environment to learn more about the function of this complex neuroendocrine system on earth.

In summary, this spaceflight experiment has provided significant new infomation concerning the issue of direct microgravity effects on pituitary cell structure and function in microgravity. From what we now know. there seems little question that some pituitary cell types directly. "sense" the lack of gravity. regardless of whether they are present in their native condition (i.e. the rat) or in a cell culture system. In terms of secretory func. tion. GH. PRL and ACTH cells appear to be the most sensitive of the six major homone-producing cell types to the low gravity environment.

\section{Acknowledgements}

This study was supported by NASA grant \#NAG8-953. As with any microgravity experiment. many capable people participated including individuals at the Hanger $L$ facility at Kennedy Space Center, the Payloads Operation Center at Marshall Spaceflight Center, and colleagues in Japan (NASDA and Mitsubishi Heavy Industries, Lid.). We also acknowledge the many useful suggestions of Dr. Hiro Kumei, Toyko Medical School, regarding use of the CCK's. Dr. Dan Deaver and Ms. Rosemary Walsh, Penn State, did the RIA analyses and photography. The superb technical assistance of Marge Hymer is also acknowledged as is Marilyn Warrender for typing 
the manuscript. Finally, our sincere thanks to the crew of STS-65 for their help in making this experiment possible.

\section{References}

Albrecht-Buehler, G. (1991) Possible mechanisms of indirect gra:iry sensing by cells. ASGSB Bull. $4(2)$. 25-34.

Cogoli. A. (1993) The effect of hypogravity and hypergravity on cells of the immune system. J. Leukos. Biol. $54,259-$ :68.

de Groor. R.. Rijken. P.. den Hertog. J.. Boonstra. J.. Verkleij. A. de Laat. S. and Kruijer. W. (1990) Micreeravily decreases c-fos inducion and serum respone element activily. J. Coll Sci. 9?. $: \because-38$.

de Groot. R. Rijken. P.. Jen Hertog. J.. Boonstril. J. Verkleij. A. de Laat. S. and Kruijer. W. (1991) Vuelear responses to protein kinase $C$ signal ransciucion are sensitive to graity changes. Exp. Coll Res. 197. $\mathbf{s}^{-9}-90$.

Farmingon. W. and Himer. W. 195,1 in enzyme immunvasidy for rat grouth homone: afplicutions to the siudy of growth hormone variants. Life Sti. 40. 2479$2: 5 s$.

Farrington. M. and H!mer. W. 19901 Grow th hormone ag. arestes in the rat adenohypophysis. Envocrinulogy 126. in 3 iv) $-16 ; 8$.

Greensfan. F., Li. C. Simpson. W. and Eians. H. 11949) Bicassuy of hypophysed growth homone. Endocrinology $45.455-463$.

Grindaland. R.. Hymer. W.. Farrington, M.. Fast. T.. Hayes, C.. Yotter. K., Patil. L. and Vasques. M. (19Si) Changes in fituitary grou th hormone cells prepured from rats flown on Sfuceliab 3. Am. J. Physiol. 252 R:09-R215.

Halstead. T.. Todd. P. and Pouers. J. (1991) Gravity and the Cell Issue. Conference Repon eds. ASCSB Bulletin 4(?). 260 .

Huttield. J. and Hymer. W. (19S\$) Flow eytometric immunotiuorescence of rat anterior pituitan ceils. Cytometry 6 , $13:-1+2$

Houben. H. and Denef C. (1990) Regulatory peprides produced in the anterior pituitary. Trends Endocrinol. Metabol. 1(8). 398-403.

Hymer. W., Grindeland, R., Salada, T., Nye, P., Grossman, E. and Lane. P. (1996) Experimental modification of rat pituitary growth hormone cell function during and after spacentight. J. Appl. Physiol.. 80(3). 9\$5-970.

H!mer. W... Salada, T., Avery, L. and Grindeland, R. (1996) Experimental modification of rat pituitary prolactin cell function during and after spaceflight. J. Appl. Physiol. 8013 .) $971-980$.

Hymer. W.. Grindeland, R.. Krasnov, I., Victorov. I., Moller. K.. Mukherjee, P., Shellenberger, K. and Vusques. M. (1992) Effects of spaceflight on rat pituitary cell function. J. Appl. Physiol. 73(2), 151S-157S.

Hymer. W. and Hatfield, J. (1983) Separation of cells from the rat anterior pituitary. In: Colowick. S. and Kaplan, X. (Ejs.). Methods in Enzymology, Academic Press, Sün Diego. vol. 103. pan H. pp. 257-287.

Hymer. W.. Wilbur. D.. Page. R.. Hibbard. E.. Kelsey. R. and Hattield. J. (1981) Pituitary hollow fiber units in viro and in vitro. Veuroendocrinology 32, 339-349.

Lewis. L: (1992) Growh Hormone What is it and what joes it Jo? Trends Endocrinol. Metabol. 3. 117-121.

Limeuse. 11. Manie. S.. Konstaninova. 1.. Ferrua. B. and Schaffar. L. (1991) Inhibition of phorbol ester-induced cell activation in microgravity. Exp. Cell Res. 197. \$2-86.

Morrison. D. (1994) Cell electrophoresis in microgratity: Past and future. In: Bauer. J. IEd.I. Call Electrophoresis. CRC Press. Inc. Boca Ruton. FL. FP. 283-314.

Perez. F. Deswer. D. and Himer. W. 199:) Why use d how gometer for endocrine cell analysis? In: de Pablo. F. Sünes. C. and Weintraub. B. IEds.). Handbook of EnJorine Rescarch Techniques. Academic Press. Sin Diego. Fp. $1: i-180$.

Signurella. A. and H:mer. W.C. (19S4) Dexelopment of an enz:me-linked immunoubsorben dasily for rat prolactin. Aral. Biochem. 1;6, $: 1:-\$ 81$.

Sinha. Y. 11992) Prolactin Vuriants. Trends Endocrinol. Metubol. isil. 100-106.

Sn! der. G. H!mer. W.C. and Snyder. J. (197i) Functional heterogeneity in somatotrophs isolated from the rat ante. rior pituitary. Endocrinology 101. 7SS-799.

Tanaka. T.. Shiu. R.. Gout. P.. Beer. C., Noble. R. and Friesen. H. (1980) A new sensitive and specific bioassay for lactogenic hormones: measurement of prolactin and grouth hormone in human serum. J. Clin. Endocrinol. Metab. 51, 10\$8-1063.

W'alker, A. (1994) Phosphorilated and nonphosphor lated frolactin isoforms. TEM 5(5). 195-200.

W'an@. Y. and Walker. A.M. (1993) Dephosphorylation of standard prolactin produces a more biologically active molecule: Evidence for antagonism between nonphosphor.lated and phosphorylated prolactin in the stimulation of $\mathrm{V}_{\mathrm{b}}$ cell proliferation. Endocrinology 133, 2156-2160.

Wilfinger, W.. Davis. J., Augustine. E. and Hymer, W. (1979) The effects of culture conditions on prolactin and and grouth hormone production by rat anterior pituitary cells. Endocrinology 105, 530-536. 